\title{
Commercial Building Energy Code Compliance Literature Review
}

\section{February 2016}

R Bartlett J Goins
M Halverson

P Cole 


\title{
DISCLAIMER
}

This report was prepared as an account of work sponsored by an agency of the United States Government. Neither the United States Government nor any agency thereof, nor Battelle Memorial Institute, nor any of their employees, makes any warranty, express or implied, or assumes any legal liability or responsibility for the accuracy, completeness, or usefulness of any information, apparatus, product, or process disclosed, or represents that its use would not infringe privately owned rights. Reference herein to any specific commercial product, process, or service by trade name, trademark, manufacturer, or otherwise does not necessarily constitute or imply its endorsement, recommendation, or favoring by the United States Government or any agency thereof, or Battelle Memorial Institute. The views and opinions of authors expressed herein do not necessarily state or reflect those of the United States Government or any agency thereof.

\author{
PACIFIC NORTHWEST NATIONAL LABORATORY \\ operated by \\ BATTELLE \\ for the \\ UNITED STATES DEPARTMENT OF ENERGY \\ under Contract DE-AC05-76RL01830
}

Printed in the United States of America
Available to DOE and DOE contractors from the Office of Scientific and Technical Information,
P.O. Box 62, Oak Ridge, TN 37831-0062;
ph: (865) 576-8401
fax: $(865)$ 576-5728
email: reports@adonis.osti.gov

\begin{abstract}
Available to the public from the National Technical Information Service, U.S. Department of Commerce, 5285 Port Royal Rd., Springfield, VA 22161 ph: (800) 553-6847 fax: $(703) 605-6900$ email: orders@ntis.fedworld.gov online ordering: http://www.ntis.gov/ordering.htm
\end{abstract}

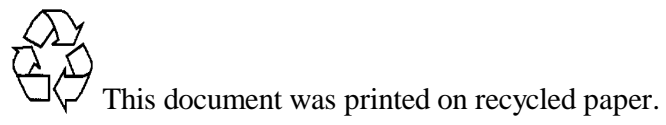




\title{
Commercial Building Energy Code Compliance Literature Review
}

\author{
R Bartlett \\ M Halverson \\ J Goins \\ P Cole
}

February 2016

Prepared for

the U.S. Department of Energy

under Contract DE-AC05-76RL01830

Pacific Northwest National Laboratory

Richland, Washington 99352 



\section{Executive Summary}

The U.S. Department of Energy (DOE) is required to provide technical assistance to states per statute. DOE, through its Building Energy Codes Program (BECP), provides technical assistance to states to implement building energy codes, including increasing and verifying compliance to ensure consumer benefits (42 USC $6833^{1}$ ). One key area in which BECP has worked over the past several years is providing resources and tools to assist states in evaluating compliance with building energy codes.

Work is already underway to formally evaluate residential energy code compliance across the United States. ${ }^{2}$ DOE is interested in pursuing a similar effort for commercial buildings and tasked the Pacific Northwest National Laboratory (PNNL) to conduct a literature review of past commercial building compliance evaluations. A total of 26 key sources were identified and reviewed as part of this effort, and several key questions are addressed with the goal of informing the development of a recommended commercial compliance evaluation methodology.

It is difficult to directly compare many of the studies as vastly different evaluation methodologies were employed, especially prior to the development of the original PNNL evaluation methodology (PNNL 2010). However, the various approaches and results are summarized and compared to the extent possible. Some of the key findings include:

- The most common problem noted almost unanimously across studies was the issue of accessing commercial code compliance documentation and buildings for evaluation. An approach that worked well in one or two studies was to use evaluators who were familiar to the building department staff (e.g., retired code officials). In addition, the most typical sample bias seemed to be introduced after experiencing problems with building recruitment.

- A compliance definition is not often specifically defined in the studies.

- Most studies focused on new construction. Most experts agree that there are significant savings opportunities associated with renovations; however, these projects are harder to find data about and to visit.

- Most of the studies used a single site visit that occurred post-occupancy. There are both advantages and disadvantages to this approach: an advantage is that all systems are installed and commissioned as applicable, but a disadvantage is that documentation may not be up to date for all systems. For example, one study noted that tenants had already redesigned the lighting by the time the site visit occurred, and the lighting documentation was no longer accurate. Another disadvantage of postoccupancy visits is that not all components are observable. When not observable, many studies used values from compliance documentation or values that met code requirements to evaluate compliance.

- Where compliance documentation was available and reviewed, several studies noted that more energy code-specific details would have been helpful and should be included as standard practice in permit submittals.

\footnotetext{
${ }^{1} 42$ USC 6833. Chapter 42, U.S. Code, Section 6833. Available at http://www.gpo.gov/fdsys/pkg/USCODE-2011title42/pdf/USCODE-2011-title42-chap81-subchapII.pdf.

${ }^{2}$ See https://eere-exchange.energy.gov/FileContent.aspx?FileID=e6fd3f56-d6cc-4db3-8d26-6b52c4e9c27a for DOE’s Funding Opportunity Announcement for residential code compliance evaluation.
} 
- States were able to show compliance rates above $80 \%$ in many cases; though these metrics may not have been based on appropriate samples. Statistical significance was often a problem for these studies.

- A few studies reported using energy simulation as part of their evaluation methodology, either to determine whole-building compliance, or as an alternative evaluation approach.

The next anticipated step in DOE's effort to improve commercial code compliance is to take the information provided in this literature review and develop a pilot compliance study. 


\section{Acronyms and Abbreviations}

ACEEE

ARRA

ASHRAE

BECP

DOE

FOA

FY

HVAC

IDFBS

IECC

IOU

LEED

LPD

NEEA

O\&M

PG\&E

PNNL

REEO

SCE

SCG

SDGE

sf

TRC
American Council for an Energy-Efficient Economy

American Recovery and Reinvestment Act of 2009

American Society of Heating, Refrigerating, and Air-Conditioning Engineers

Building Energy Codes Program

U.S. Department of Energy

funding opportunity announcement

fiscal year

heating, ventilation, and air conditioning

Indiana Department of Fire and Building Services

International Energy Conservation Code

investor-owned utility

Leadership in Energy and Environmental Design

lighting power density

Northwest Energy Efficiency Alliance

operations and maintenance

Pacific Gas \& Electric

Pacific Northwest National Laboratory

regional energy efficiency organization

Southern California Edison

Southern California Gas

San Diego Gas \& Electric

square feet

total resource cost 



\section{Contents}

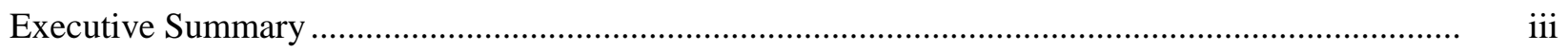

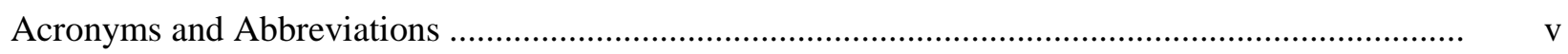

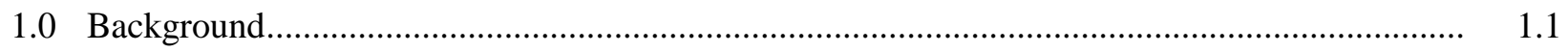

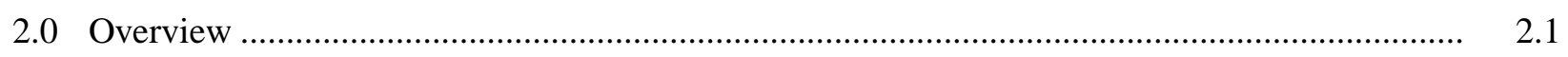

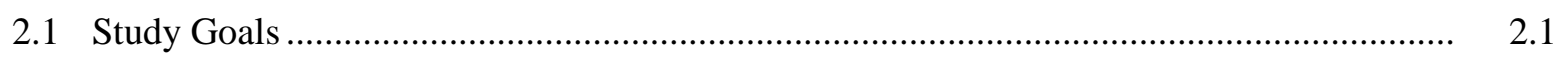

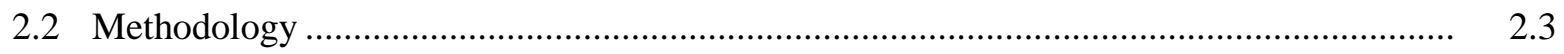

2.2.1 Compliance Evaluation Approaches …............................................................. 2.3

2.2.2 Compliance Evaluation Steps.................................................................... 2.4

3.0 Key Research Questions ............................................................................................... 3.1

3.1 Compliance Definition ............................................................................................ 3.1

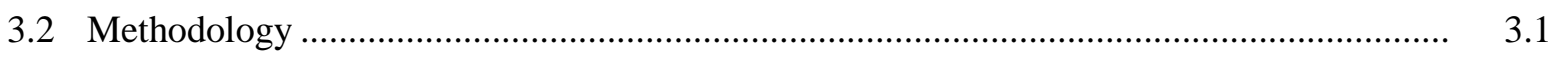

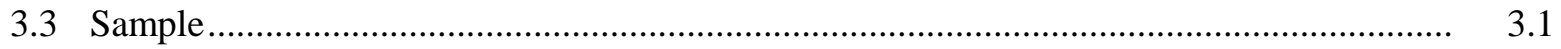

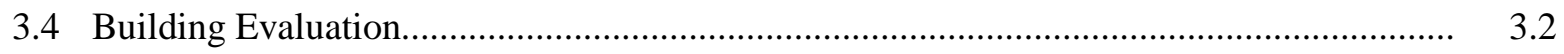

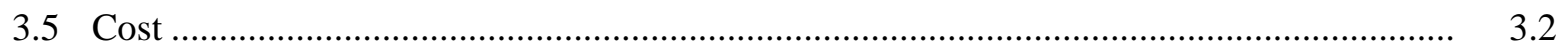

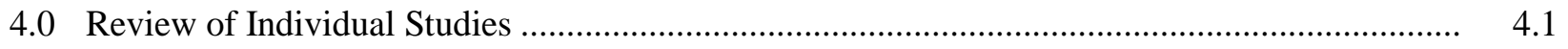

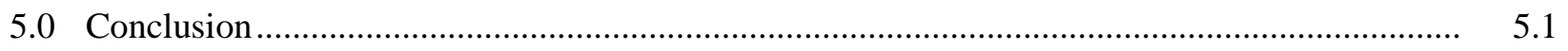

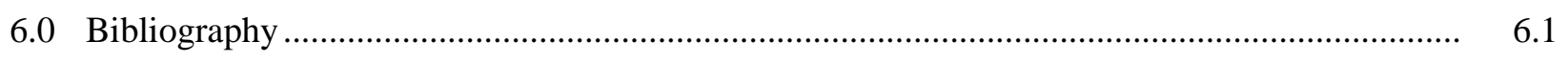

Appendix A - Commercial Compliance Studies ......................................................................... A.1

Appendix B - Other Methodologies and Studies ........................................................................ B.1

Appendix C - Comparison of Sample Quality and Compliance Metrics ......................................... C.1 


\section{Tables}

2.1 Depicts the Categories and Associated Questions Addressed as Applicable in the Literature Review

2.2 Compliance Evaluation Study by Method ........................................................................ 2.2

2.3 Systems Covered by Compliance Evaluation Study ................................................................. 2.3

2.4 Research Goal by Compliance Evaluation Method ..................................................................... 2.4

2.5 Evaluation Studies by Approach Type ............................................................................. 2.4

2.6 Compliance Evaluation Steps by Approach.......................................................................... 2.5 


\subsection{Background}

The U.S. Department of Energy (DOE) Building Energy Codes Program (BECP) is required to provide technical assistance to states per statute. This includes providing technical assistance to states to implement building energy codes including increasing and verifying compliance to ensure consumer benefits (42 USC $6833^{1}$ ). One key area in which BECP has worked over the past several years is providing resources and tools to assist states in evaluating compliance with building energy codes.

BECP's compliance evaluation efforts began with the development of a compliance evaluation methodology (covering both residential and commercial buildings, both new construction and retrofits) and associated tools to support the American Recovery and Reinvestment Act (ARRA) of 2009². ARRA required states to develop "a plan for the jurisdiction achieving compliance with the building energy code or codes described in subparagraphs (A) and (B) within 8 years of the date of enactment of this Act in at least 90 percent of new and renovated residential and commercial building space. Such plan shall include active training and enforcement programs and measurement of the rate of compliance each year." Eight pilot studies in nine states were conducted using this methodology, and the three studies that evaluated commercial buildings are included in this review. The tools that were developed and made available as part of that work include: 1) the State Sample Generator: an online tool that generates a representative sample set distributed across building size and climate zone for each state; 2) compliance checklists; and 3) Score+Store: an online tool that collects checklist data, determines individual building scores, and calculates an average compliance score for the sample set.

In Fiscal Year (FY) 2014, DOE issued a Funding Opportunity Announcement (FOA) related to compliance improvement for new residential construction. ${ }^{3}$ In support of the FOA, BECP worked to develop a methodology and supporting resources focused solely on new residential construction. While the residential efforts will continue in FY 2015, DOE is also interested in addressing commercial construction. As a first step, DOE asked Pacific Northwest National Laboratory (PNNL) to conduct a literature review of existing commercial compliance evaluation reports. PNNL identified 26 reports for review as listed in the Bibliography section of this document. Sources were identified using references listed in various seminal studies, review of recent American Council for an Energy-Efficient Economy (ACEEE) Summer Study topics, and through a request sent to the Regional Energy Efficiency Organizations (REEOs).

In summary, those 26 papers represent:

- DOE's ARRA pilot studies

- State compliance evaluation studies

- Studies specifically related to California that were typically commissioned by one of the investorowned utilities: Pacific Gas and Electric (PG\&E), San Diego Gas and Electric (SDGE), Southern California Gas (SGG), and Southern California Edison (SCE)

- Papers regarding proposed methodologies for commercial building energy code compliance and enforcement and utility attribution of savings resulting from compliance with building energy codes.

\footnotetext{
${ }^{1} 42$ USC 6833. Chapter 42, U.S. Code, Section 6833. Available at http://www.gpo.gov/fdsys/pkg/USCODE-2011title42/pdf/USCODE-2011-title42-chap81-subchapII.pdf.

${ }^{2}$ https://www.energycodes.gov/about/statutory-requirements

3 http://energy.gov/eere/buildings/articles/apply-increase-residential-energy-code-compliance-rates-de-foa-0000953
} 



\subsection{Overview}

Several key questions were identified to be addressed in this literature review and are listed in Table 2.1 by category: compliance definition, methodology, sample size, building evaluation, and cost. Given the number of details to be summarized for each study, the studies were characterized and grouped in several ways for ease of reporting; and tables and summaries are used when possible. Two key areas explored in the literature review were study goals and methodologies employed.

Table 2.1. Depicts the Categories and Associated Questions Addressed as Applicable in the Literature Review

\begin{tabular}{|c|c|}
\hline Category & Question \\
\hline Compliance Definition & Did the study define compliance? If yes, what was the definition? \\
\hline Methodology & Did the methodology define the research question? If yes, what was the question? \\
\hline Methodology & $\begin{array}{l}\text { Did the study validate the hypothesis of their test method to determine if it answered the } \\
\text { research question? }\end{array}$ \\
\hline Methodology & What approach did the study use to answer the research question? \\
\hline Methodology & Did the study look at retrofits? \\
\hline Sample Size & What is sampling method used in the study? \\
\hline Sample Size & What was the source of data used to generate the sample? \\
\hline Sample Size & Was stratification used in the sample? If yes, what sort? \\
\hline Sample Size & What was the sample size used in the study? \\
\hline Sample Size & Was the sample considered to be representative? \\
\hline Building Evaluation & How did the study team gain access to design documents and building sites? \\
\hline Building Evaluation & Did the study involve plan review? \\
\hline Building Evaluation & $\begin{array}{l}\text { Did the study involve site visits? If yes, how many site visits were made to each building } \\
\text { in the study? }\end{array}$ \\
\hline Building Evaluation & $\begin{array}{l}\text { Did the study verify every requirement in the energy code? If no, which requirements did } \\
\text { the study ignore? }\end{array}$ \\
\hline Building Evaluation & Did the study include different approaches? If yes, were these approaches shortcuts? \\
\hline Building Evaluation & Did the study have a methodology for developing shortcuts? \\
\hline Building Evaluation & Did the study evaluate if these shortcuts worked? \\
\hline Building Evaluation & Did the study evaluate the energy impact of non-compliance? \\
\hline Building Evaluation & Did the study evaluate whether or not controls complied? \\
\hline Cost & $\begin{array}{l}\text { Did the study report costs? If yes, how much did the study cost per building or in total or } \\
\text { both? }\end{array}$ \\
\hline Cost & Did the study report level of effort? If yes, what was the level of effort for the study? \\
\hline
\end{tabular}

\subsection{Study Goals}

Most of the studies had stated research goals. The goals were characterized into six categories (many studies had more than one goal): 
- Compliance rate: derive a compliance rate. In most cases, actual data was gathered and a compliance rate generated. In one case a method was proposed but no data was gathered.

- Compliance evaluation methodology: describe and critique one or more existing methodologies but does not provide a result or data.

- Enforcement effectiveness: improve code enforcement, usually for a state.

- Enforcement methodology: improve code enforcement for a state.

- Energy use: attribute energy savings estimates to compliance or enforcement activities.

- Utility program attribution: attribute energy savings to utilities’ code compliance programs.

Table 2.2 shows the studies by state and associated goals. When a particular state(s) is not applicable, "NA" is shown in the second column. Table 2.3 identifies the systems evaluated in each study.

Table 2.2. Compliance Evaluation Study by Method

\begin{tabular}{|c|c|c|c|c|c|c|c|}
\hline \multirow[b]{2}{*}{ Reference } & \multirow[b]{2}{*}{ State } & \multicolumn{6}{|c|}{ Study goal: to evaluate } \\
\hline & & $\begin{array}{l}\text { Compliance } \\
\text { rate }\end{array}$ & $\begin{array}{l}\text { Compliance } \\
\text { evaluation } \\
\text { methodology }\end{array}$ & $\begin{array}{l}\text { Enforcement } \\
\text { effectiveness }\end{array}$ & $\begin{array}{l}\text { Enforcement } \\
\text { methodology }\end{array}$ & $\begin{array}{l}\text { Energy } \\
\text { use/ } \\
\text { savings }\end{array}$ & $\begin{array}{l}\text { Utility } \\
\text { program } \\
\text { attribution }\end{array}$ \\
\hline APEC 2011 & IL 2011 & $\mathrm{X}$ & $\mathrm{X}$ & & & & \\
\hline BMG 2005 & IN & $X$ & & & & & \\
\hline BMG 2014 & NE & & $\mathrm{X}$ & & & $\mathrm{X}$ & \\
\hline $\begin{array}{r}\text { Ecotope } \\
2008 \\
\end{array}$ & $\begin{array}{l}\text { ID, MT, } \\
\text { OR, WA } \\
2008\end{array}$ & $X$ & & & & & \\
\hline $\begin{array}{r}\text { Baylon et } \\
\text { al. } 1997\end{array}$ & WA 1997 & $\mathrm{X}$ & & & & & \\
\hline $\begin{array}{r}\text { Baylon } \\
1991 \\
\end{array}$ & $\begin{array}{l}\text { WA \& } \\
\text { OR } 1991\end{array}$ & $\mathrm{X}$ & $\mathrm{X}$ & & & & \\
\hline $\begin{array}{r}\text { Elnecave et } \\
\text { al. } 2014 \\
\end{array}$ & IL 2014 & $\mathrm{X}$ & $\mathrm{X}$ & & & $\mathrm{X}$ & $\mathrm{X}$ \\
\hline $\begin{array}{r}\text { KEMA } \\
2010 \\
\end{array}$ & CA 2010 & $\mathrm{X}$ & & & & $\mathrm{X}$ & $\mathrm{X}$ \\
\hline $\begin{array}{r}\text { KEMA } \\
2012 \\
\end{array}$ & MA 2012 & $\mathrm{X}$ & & & & & \\
\hline $\begin{array}{r}\text { MPUC } \\
2004 \\
\end{array}$ & NA & & $\mathrm{X}$ & $\mathrm{X}$ & $\mathrm{X}$ & & \\
\hline Meres 2012 & NA & & & $\mathrm{X}$ & $\mathrm{X}$ & & \\
\hline $\begin{array}{r}\text { Misuriello } \\
2010\end{array}$ & NA & & $\mathrm{X}$ & $\mathrm{X}$ & & & \\
\hline $\begin{array}{r}\text { Navigant } \\
2012\end{array}$ & VT 2011 & & $\mathrm{X}$ & $\mathrm{X}$ & & & \\
\hline $\begin{array}{r}\text { Navigant } \\
2011 \\
\end{array}$ & NA & & & $\mathrm{X}$ & $\mathrm{X}$ & & \\
\hline $\begin{array}{r}\text { Southface } \\
2012 \\
\end{array}$ & NA & & & $\mathrm{X}$ & $\mathrm{X}$ & & \\
\hline DOE 2013 & $\begin{array}{l}\text { GA, WI, } \\
\text { UT, VY, } \\
\text { NY }\end{array}$ & $\mathrm{X}$ & & & & & \\
\hline
\end{tabular}


Table 2.2. (Contd)

\begin{tabular}{|c|c|c|c|c|c|c|c|}
\hline \multirow[b]{2}{*}{ Reference } & \multirow[b]{2}{*}{ State } & \multicolumn{6}{|c|}{ Study goal: to evaluate } \\
\hline & & $\begin{array}{l}\text { Compliance } \\
\text { rate }\end{array}$ & $\begin{array}{l}\text { Compliance } \\
\text { evaluation } \\
\text { methodology }\end{array}$ & $\begin{array}{l}\text { Enforcement } \\
\text { effectiveness }\end{array}$ & $\begin{array}{l}\text { Enforcement } \\
\text { methodology }\end{array}$ & $\begin{array}{l}\text { Energy } \\
\text { use/ } \\
\text { savings }\end{array}$ & $\begin{array}{l}\text { Utility } \\
\text { program } \\
\text { attribution }\end{array}$ \\
\hline PNNL 2010 & NA & $\mathrm{X}$ & $\mathrm{X}$ & & & & \\
\hline VEIC 2012 & NY & $\mathrm{X}$ & $\mathrm{X}$ & & & & \\
\hline $\begin{array}{r}\text { Wirtshafter } \\
2011\end{array}$ & NY & $\mathrm{X}$ & $\mathrm{X}$ & & & & \\
\hline $\begin{array}{r}\text { Baylon } \\
1995\end{array}$ & $\begin{array}{l}\text { WA \& } \\
\text { OR } 1991\end{array}$ & $\mathrm{X}$ & & $\mathrm{X}$ & $\mathrm{X}$ & & \\
\hline
\end{tabular}

Table 2.3. Systems Covered by Compliance Evaluation Study

\begin{tabular}{|c|c|c|c|c|c|c|}
\hline & Study & Envelope & HVAC & Lighting & Other & Power \\
\hline \multirow{3}{*}{$\underline{\text { Pilot Studies }}$} & GA 2011 & $\mathrm{X}$ & $\mathrm{X}$ & $\mathrm{X}$ & $\mathrm{X}$ & $\mathrm{X}$ \\
\hline & WI 2011 & $\mathrm{X}$ & $\mathrm{X}$ & $\mathrm{X}$ & $\mathrm{X}$ & $\mathrm{X}$ \\
\hline & UT 2011 & $\mathrm{X}$ & $\mathrm{X}$ & $\mathrm{X}$ & $\mathrm{X}$ & $\mathrm{X}$ \\
\hline \multirow{10}{*}{$\begin{array}{c}\begin{array}{c}\text { Other } \\
\text { evaluation }\end{array} \\
\underline{\text { studies }}\end{array}$} & $\begin{array}{c}\text { WA \& OR } \\
1991\end{array}$ & $\mathrm{X}$ & $\mathrm{X}$ & $\mathrm{X}$ & & \\
\hline & WA 1997 & $\mathrm{X}$ & $\mathrm{X}$ & $\mathrm{X}$ & & \\
\hline & $\begin{array}{l}\text { ID, MT, OR, } \\
\text { WA } 2008 \\
\end{array}$ & $\mathrm{X}$ & $\mathrm{X}$ & $\mathrm{X}$ & & \\
\hline & CA 2010 & & Partial X & Partial X & & \\
\hline & IL 2011 & $\mathrm{X}$ & $\mathrm{X}$ & $\mathrm{X}$ & $\mathrm{X}$ & $\mathrm{X}$ \\
\hline & IL 2014 & \multicolumn{5}{|c|}{ Not reported, but used BECP approach } \\
\hline & NE 2014 & $\mathrm{X}$ & $\mathrm{X}$ & $\mathrm{X}$ & $\mathrm{X}$ & $\mathrm{X}$ \\
\hline & MA 2012 & $\mathrm{X}$ & $\mathrm{X}$ & $\mathrm{X}$ & & \\
\hline & NY 2012 & $\mathrm{X}$ & $\mathrm{X}$ & $\mathrm{X}$ & $\mathrm{X}$ & $\mathrm{X}$ \\
\hline & VT 2011 & $\mathrm{X}$ & $\mathrm{X}$ & $\mathrm{X}$ & $\mathrm{X}$ & $\mathrm{X}$ \\
\hline
\end{tabular}

\subsection{Methodology}

Many of the compliance evaluation studies that have taken place since DOE's ARRA-related studies in 2010 and 2011 have used the BECP compliance evaluation methodology, or a variant of it. Although most of the studies reviewed used the BECP methodology, there were variations. The following sections characterize the compliance evaluation approaches and steps used in the studies.

\subsubsection{Compliance Evaluation Approaches}

Several compliance evaluation approaches were used; however, most of the studies followed one of three approaches. Table 2.4 depicts the research goals covered by the various approaches. These approaches are characterized as:

- BECP (as described in PNNL 2010) is the most widely used, although with variations in some cases 
- Northwest has changed as time has passed, from original seminal studies to variations of the BECP approach

- Attribution is mostly a combination of compliance rate evaluation with utility program attribution

Table 2.4. Research Goal by Compliance Evaluation Method

\begin{tabular}{lcccccc}
\hline & $\begin{array}{l}\text { Compliance } \\
\text { rate }\end{array}$ & $\begin{array}{l}\text { Compliance } \\
\text { evaluation } \\
\text { methodology }\end{array}$ & $\begin{array}{l}\text { Enforcement } \\
\text { effectiveness }\end{array}$ & $\begin{array}{l}\text { Enforcement } \\
\text { methodology }\end{array}$ & $\begin{array}{l}\text { Energy } \\
\text { use/savings }\end{array}$ & $\begin{array}{l}\text { Utility } \\
\text { program } \\
\text { attribution }\end{array}$ \\
\hline BECP & $\mathrm{X}$ & $\mathrm{X}$ & & & & \\
Northwest & $\mathrm{X}$ & & $\mathrm{X}$ & $\mathrm{X}$ & $\mathrm{X}$ & \\
Attribution & $\mathrm{X}$ & & & & $\mathrm{X}$ & $\mathrm{X}$ \\
\hline
\end{tabular}

Table 2.5 shows compliance studies grouped as either "pilot studies” or "other evaluation studies" and their associated methodology approaches, where applicable.

Table 2.5. Evaluation Studies by Approach Type

\begin{tabular}{|c|c|c|c|c|}
\hline & Study & BECP & Northwest & Attribution \\
\hline \multirow{3}{*}{ Pilot Studies } & GA 2011 & $\mathrm{X}$ & & \\
\hline & WI 2011 & $\mathrm{X}$ & & \\
\hline & UT 2011 & $\mathrm{X}$ & & \\
\hline \multirow{11}{*}{ Other evaluation studies } & WA \& OR 1991 & & $\mathrm{X}$ & \\
\hline & WA \& OR 1992 & & $\mathrm{X}$ & \\
\hline & WA 1997 & & $\mathrm{X}$ & \\
\hline & ID, MT, OR, WA 2008 & & $\mathrm{X}$ & \\
\hline & CA 2010 & & & $\mathrm{X}$ \\
\hline & IL 2011 & $X$ & & \\
\hline & IL 2014 & & & $\mathrm{X}$ \\
\hline & NE 2014 & $\mathrm{X}$ & & \\
\hline & MA 2012 & & & $\mathrm{X}$ \\
\hline & NY 2012 & $\mathrm{X}$ & & \\
\hline & VT 2011 & $\mathrm{X}$ & & \\
\hline
\end{tabular}

\subsubsection{Compliance Evaluation Steps}

Typically, the studies used some combination of six main steps in compliance evaluation: create affinity group, create compliance baseline, interview code officials, interview design team, plan review, and field inspection. Each step is further defined below. Table 2.6 shows the steps involved by approach. 
Table 2.6. Compliance Evaluation Steps by Approach

\begin{tabular}{lrrc}
\hline Step & BECP & Northwest & Attribution \\
\hline Create affinity group & $\mathrm{X}$ & $\mathrm{X}$ & \\
Create compliance baseline & $\mathrm{X}$ & & $\mathrm{X}$ \\
Interview code officials & & $\mathrm{X}$ & \\
Interview design team & & $\mathrm{X}$ & $\mathrm{X}$ \\
Plan review & $\mathrm{X}$ & $\mathrm{X}$ & $\mathrm{X}$ \\
Field inspection & $\mathrm{X}$ & & \\
\hline
\end{tabular}

\subsubsection{Create Affinity Group}

The purpose of this step was to gather and engage stakeholders in the code compliance evaluation process. In some cases, this group helped to gather data and generate the state-wide permit population. Unfortunately, in a few cases this group was used to identify specific buildings, which likely biased the samples.

\subsubsection{Create Compliance Baseline}

The BECP method is focused on establishing a compliance baseline. In several cases, baselines from previous compliance studies were used. In others, the baselines were derived from other data sources. All three of these approaches can lead to a valid baseline. In at least one case, however, there was an assumed baseline; this is not likely to be a good solution.

\subsubsection{Interviews}

Many studies used interviews as part of their compliance evaluation methodology and included questions ranging from general practices and attitudes related to energy code compliance to detailed questions about specific commercial building projects. The actual parties interviewed included code officials, design teams, and others depending upon the particular study goals. Interviewing each of these stakeholders is further described below.

\section{Code Officials}

Interviews with code officials can help in understanding specifics about building design and the commercial building marketplace, enforcement activities and compliance challenges in a jurisdiction. They can also be useful for identifying affinity group members. Interviews need careful attention if they are to produce useful information, however, and a structured set of questions is critical.

\section{Design Teams}

These interviews can help the compliance evaluation team understand the architect and engineer experience around compliance in their state and learn about their level of understanding of energy codes. Several studies found, however, that architects and engineers tended to relate generalities based on their experiences rather than project-specific details. The information provided can be useful, but it is difficult 
at times to get architects and engineers to be willing to provide details about specific projects after those projects are completed.

\subsubsection{Plan Review}

Plan reviews were used to gather specifications and other compliance information from the drawings. A number of studies commented on the need for more standardization in how compliance is demonstrated on construction and compliance documentation. Drawings were obtained from the design team or from jurisdictions in places where they were cooperative and where they were available. In studies where the building samples were largely occupied buildings, data from the compliance documentation was heavily relied upon to estimate compliance.

\subsubsection{Field Inspection}

On-site field inspection was used to verify as-built conditions. This step had the greatest variation across the studies, with some studies focused on only certain systems within a building (building envelope, lighting, mechanical), only certain building types (retail, office), only occupied buildings, etc. Many of the studies conducted field inspection post-occupancy with only one site visit. 


\subsection{Key Research Questions}

Several key questions were identified to be addressed in the literature review, and the questions were categorized as compliance definition, methodology, sample, building evaluation, and cost. A summary narrative for each category is included in this section, with study-specific details provided as part of the study overviews in Appendix A. Table 2.1 provides a complete list of the questions. Questions related to sample quality and compliance evaluation metrics are addressed using a tabular format in Appendix C.

\subsection{Compliance Definition}

Very few studies explicitly included a definition of compliance. Since many of the more recent studies followed the BECP methodology, the percentage of applicable code requirements that were met (weighted by three tiers) was reported. In the earlier studies (e.g., Ecotope 1992), compliance was based on the allowable heat loss rate.

\subsection{Methodology}

It appears that methodological deviations were driven mostly by real world concerns of cost, efficiency, and schedule. The steps outlined in the BECP methodology (PNNL 2010) were followed in many studies, but some studies instead focused on particular building types or building systems, choosing specific requirements to evaluate for a particular system (e.g., HVAC efficiency, sizing, and economizers only), or used only one site visit as was common in several studies that evaluated occupied buildings only.

In many cases, when specific items were not observable for a compliance evaluation, code-compliant values or values from plans were allowed to be inserted. Substitutions such as these can lead to falsely high or low compliance rates.

Research goals were stated for a number of the studies and typically consisted of establishing a baseline compliance rate. Although unstated, the reality for most of the studies was the goal to answer the individual study research questions as cost-effectively and easily as possible.

Most of the studies focused on new construction rather than retrofits. The more successful evaluations seemed to occur when all of the steps described above were included. Almost without exception, one of the biggest issues with the studies was recruiting buildings. Addressing that issue sometimes led to bias being introduced into the sample.

\subsection{Sample}

Many of the studies had statistically valid samples that did a good job of representing the geographic areas within the state. Most of the studies used data from McGraw Hill Dodge Construction Data ${ }^{1}$ (Dodge), either as part of the BECP Sample Generator or directly from Dodge, to derive the samples. Sample size varied a great deal across studies from a few observations to several hundred. In the studies

\footnotetext{
${ }^{1}$ See http://dodge.construction.com/ for description of the McGraw Hill construction data.
} 
with small samples, it is impossible to state that the results are representative of the sample population, but the study results can still be beneficial. Sample stratification occurred in several studies, with building size being the most common. The most typical sample bias seemed to be introduced after experiencing problems with building recruitment.

\subsection{Building Evaluation}

There were several evaluation steps that were common to most of the studies including: plan review, field inspection (only in many cases it was limited to one site visit), and interviews. Limiting the evaluation to one site visit meant that there were several items that were unobservable. In nearly all of the cases, the studies reported that access to documentation and the building sites was very difficult and time consuming. One exception was Wisconsin (DOE 2013), but in that case the state is in charge of all enforcement activities and maintains its own construction database. An approach that worked well in one or two studies was to use evaluators who were familiar to the building department staff (e.g., retired code officials).

More recent studies included compliance evaluation against all applicable code requirements. Some of the older studies focused on areas of particular concern (e.g., major systems). The determination whether past studies considered compliance with controls requirements was of key concern for this literature review, and while many studies named controls as being included in the studies (at least during plan review), it is not clear that any study was comprehensive in this regard.

Some studies used shortcuts such as spot checking during on-site reviews (this seemed most common for lighting system evaluations), but the most frequent shortcut was limiting the evaluation to one postconstruction visit. In some cases, compliance documentation was used to supplement the postconstruction visit for items that were not observable. In cases where shortcuts were taken, most of the studies acknowledged the pitfalls of their use, including the lack of ability to observe all code requirements.

Another item of particular interest was whether any of the studies evaluated the implications of noncompliance. One study (VEIC 2012), estimated the lost annual energy savings from non-compliance as $\$ 8.8$ million. No other study included in the literature review provided any details about the effects of non-compliance.

\subsection{Cost}

Study costs were not routinely reported and were noted for only four of the studies included in this literature review: three DOE ARRA-related compliance evaluations (GA, WI, Northwest Lighting Study) and the IL study (APEC 2011). The DOE UT study included both residential and commercial building evaluations, but the costs were not broken out for commercial buildings only, so that study was not included in calculating an average per building cost. The four studies encompassed 127 building at a total cost of $\$ 511,000$. This results in an average cost per building of approximately $\$ 4,000$. It is important to note, however, that the sample size of four studies is very small, and this average cost may not be considered representative. 


\subsection{Review of Individual Studies}

In total, over 20 studies were reviewed. During the course of the review, it was determined that a few of the studies were too general to be of benefit to this literature review, but the citations are included for completeness. The bulk of the sources represent several compliance evaluation studies of commercial buildings performed in the past 20+ years. Most of the studies focused on particular states and are therefore ordered by state and summarized in Appendix A. Rather than reporting on actual compliance studies, two of the sources describe compliance evaluation methodologies developed by various organizations, and those summaries are provided in Appendix B. 



\subsection{Conclusion}

There is much to be learned from past commercial compliance evaluation studies. The studies reviewed as part of this literature review used various methodologies and approaches that encompass most of the possible scenarios to be used in a commercial compliance study as discussed by BECP staff. There were a few studies that created their own databases of permit data as part of their evaluation activities. The best population to compare against when available is actual permits. The Vermont study (Navigant 2012) did exceedingly well in terms of sample quality. The New York study (VEIC 2012) was very concerned with method quality and took great care to present and evaluate a number of methodological approaches.

Some of the key findings from the literature review include:

- The most common problem noted almost unanimously across studies was the issue of accessing commercial code compliance documentation and buildings for evaluation. An approach that worked well in one or two studies was to use evaluators who were familiar to the building department staff (e.g., retired code officials). In addition, the most typical sample bias seemed to be introduced after experiencing problems with building recruitment.

- A compliance definition is not often specifically defined in the studies.

- Most studies focused on new construction. Most experts agree that there are significant savings opportunities associated with renovations; however, these projects are harder to find data about and to visit.

- Most of the studies used a single site visit that occurred post-occupancy. There are both advantages and disadvantages to this approach: an advantage is that all systems are installed and commissioned as applicable, but a disadvantage is that documentation may not be up to date for all systems. For example, one study noted that tenants had already redesigned the lighting by the time the site visit occurred, and the lighting documentation was no longer accurate. Another disadvantage of postoccupancy visits is that not all components are observable. When not observable, many studies used values from compliance documentation or values that met code requirements to evaluate compliance.

- Where compliance documentation was available and reviewed, several studies noted that more energy code-specific details would have been helpful and should be required in permit submittals.

- States were able to show compliance rates above $80 \%$ in many cases; though these metrics may not have been based on appropriate samples. Statistical significance was often a problem for these studies.

- A few studies reported using energy simulation as part of their evaluation methodology, either to determine whole-building compliance, or as an alternative evaluation approach.

It is clear that statistically representative evaluations are costly and time consuming, especially when one considers various building types and sizes. Add to that the number of systems and building components found in buildings, and the effort can seem overwhelming. The most efficient approach may be to focus on specific energy systems or components of commercial buildings, perhaps those that are estimated to use the most energy. The next anticipated step in DOE's effort to improve commercial code compliance is to take the information provided in this literature review and develop a pilot compliance study. 



\subsection{Bibliography}

Association of Professional Energy Consultants, Inc. (APEC). Measuring the Baseline Compliance Rate for Residential and Non-Residential Buildings in Illinois Against the 2009 International Energy Conservation Code. June 2011. Available at https://www.illinois.gov/dceo/whyillinois/KeyIndustries/Energy/Documents/FinalReport_BaselineCompl ianceStudy.pdf

Baylon, David. Pilot Study: Commercial Building Energy Code Compliance Evaluation, July 1991. Available at http://www.ecotope.com/wp/wpcontent/uploads/2014/06/1991_016_CommercialBuildingEnergyCodePilot.pdf.

Baylon, David, Mark Frankel, and Curtis Clark. Energy Code Compliance in Commercial Buildings in Washington and Oregon. Ecotope. May 22, 1992. Available at http://www.ecotope.com/wp/wpcontent/uploads/2014/06/1992 003 EnergyCodeCompliance-RESIZED.pdf

Baylon, David. 1995. Compliance Procedures for Commercial Buildings. Memorandum from David Baylon of Ecotope to Kevin Madison of Utility Code Group. Available at http://www.ecotope.com/wp/wpcontent/uploads/2014/06/1995 015 ComplianceProceduresCommercialMemo.pdf .

Baylon, David, Aaron Housenecht, Jonathan Heller, and Les Tumidaj. Compliance with the 1994 Washington State Nonresidential Energy Code, June 1997. Available at http://www.ecotope.com/wp/wpcontent/uploads/2014/06/1997 005 Compliance1994Washington.pdf.

Britt Makela Group. Nebraska Commercial Energy Code Compliance Report for the 2009 International Energy Conservation Code, June 2014. Available at http://www.neo.ne.gov/NECommComplianceStudy.pdf.

Cadmus Group. Draft Evaluation Plan, February 2012. Available at http://www.energydataweb.com/cpucFiles/68/20102012CodesandStandardsEvaluationPlan_1.pdf.

Cadmus Group. Attributing Building Energy Code Savings to Energy Efficiency Programs. February 2013. Prepared for NEEP, IEE, and IMT. Available at http://www.neep.org/sites/default/files/resources/NEEP_IMT_IEE_Codes\%20Attribution\%20FINAL\%20 Report\%2002_16_2013.pdf.

Ecotope. Baseline Characteristics of the 2002-2004 Nonresidential Sector: Idaho, Montana, Oregon, and Washington, July 2008. Available at http://www.ecotope.com/wp/wpcontent/uploads/2014/06/2008_001_BaselineCharacteristics2002.pdf.

Elnecave, Isaac, Hammad Chaudry, and Stefano Galiasso. "I Want CANDI: Establishing a Utility Code Compliance Program in Illinois,” 2014. Available at http://aceee.org/files/proceedings/2014/data/papers/6-963.pdf.

Energy Futures Group. Vermont Energy Code Compliance Plan: Achieving 90\% Compliance by 2017, 2012. Available at http://www.leg.state.vt.us/reports/2012ExternalReports/280507.pdf. 
Heschong Mahone Group. 2009. SCE Codes \& Standards Process and Market Assessment Study. Prepared for Southern California Edison. Available at

http://www.calmac.org/publications/C\&S_Combined_Study_Report_041509.pdf .

Madison, Kevin and David Baylon. Compliance with the 1994 Nonresidential Washington State Energy Code, 1998. Available at http://aceee.org/files/proceedings/1998/data/papers/0423.PDF.

KEMA. California Investor Owned Utilities' Codes and Standard Program Evaluation for Program Year 2006-2008, 2010. Available at

http://www.calmac.org/publications/Codes Standards_Vol III FinalEvaluationReportUpdated 0412201 $\underline{0 . p d f}$.

KEMA. Code Compliance Baseline Study: Massachusetts Energy Efficiency Programs Large Commercial and Industrial Evaluation, 2012. Available at http://ma-eeac.org/wordpress/wpcontent/uploads/Code-Compliance-Baseline-Study.pdf.

Khawaja, M. Sami, Allen Lee, and Michelle Levy. 2007. Statewide Codes and Standards Market Adoption and Noncompliance Rates, Final Report CPUC Program No. 1134-04, SCE00224.01. Quantec, LLC. Available at http://www.calmac.org/publications/Codes_and_Standards_Final_Report.pdf.

Maine Public Utilities Commission. Investigation of Building Code Compliance and Enforcement Methods, 2004. Available at http://maine.gov/mpuc/legislative/archive/2005legislation/Enforcement\%20Report\%20final.pdf.

Meres, Ryan, Jeremy Sigmon, Mike DeWein, and Ken Garrett. "Successful Strategies for Improving Compliance with Building Energy Codes,” 2012.

http://www.aceee.org/files/proceedings/2012/data/papers/0193-000112.pdf.

Misuriello, Harry, Sarah Penney, Maggie Eldridge, and Ben Foster. "Lessons Learned from Building Energy Code Compliance and Enforcement Evaluation Studies,” 2010. Available at https://www.aceee.org/files/proceedings/2010/data/papers/2185.pdf.

Navigant. 2011 Vermont Market Characterization and Assessment Study, December 2012. Available at http://publicservice.vermont.gov/sites/psd/files/Topics/Energy_Efficiency/EVT_Performance_Eval/VT\% 20CI\%20New\%20Construction\%20Market\%20Assessment\%20and\%20Characterization_FINAL_201212-21.pdf.

Navigant. Utah Energy Code Compliance Roadmap: A Best Path Forward, April 2011. Available at http://mn.gov/commerce/energy/images/Utah_Final_Study.pdf.

Pacific Northwest National Laboratory. Measuring State Energy Code Compliance, March 2010. Available at https://www.energycodes.gov/sites/default/files/documents/MeasuringStateCompliance.pdf.

Seiden, K., A. West, M. Perussi, S. Reeves, and N. Vellinga. 2008. NEEA Codes and Standards Support Project: MPER\#2. Market Progress Evaluation Report. Report \#E08-184. Prepared by Quantec for the Northwest Energy Efficiency Alliance. Available at http://www.nwalliance.org/research/reports/E08184.pdf. Portland, OR: Quantec, LLC.

Southface Energy Institute. Building Department Pilot Study: Guidance of Effective Enforcement of Georgia’s Energy Code, February 2012. Available at 
http://www.dca.state.ga.us/development/constructioncodes/programs/documents/cc/Building_Department _Pilot_Study_GEFA_Release_8-16-12.pdf.

U.S. Department of Energy. 90 \% Compliance Pilot Studies Final Report, June 2013. Available at http://www.energycodes.gov/sites/default/files/documents/Compliance\%20Pilot\%20Studies\%20Final\%2 0Report.pdf.

Vermont Energy Investment Corporation. New York Energy Code Compliance Study, January 2012 (revised January 2014). Available at https://www.google.com/url?sa=t\&rct=j\&q=\&esrc=s\&source=web\&cd=1\&cad=rja\&uact=8\&ved=0CB4 QFjAA\&url=https\%3A\%2F\%2Fwww.nyserda.ny.gov\%2F\%2Fmedia\%2FFiles\%2FPublications\%2FResearch\%2FEnergy-Efficiency-Services\%2FNew-YorkEnergy-Code-Compliance-

Study.pdf\&ei=agtQVNrOHNLjyASr3IKQBg\&usg=AFQjCNHSD8Nr5shWyYZkNyAvLNAnpum0Xg

Wirtshafter, Robert, Betsy Harper, Richard Faesy, Glenn Reed, Jennifer Chiodo, Eveline Killian, and Kevin George. "The Costs and Benefits of Measuring If States Meet 90\% Compliance with Building Codes,” 2011. Available at http://www.iepec.org/conf-docs/papers/2011PapersTOC/papers/014.pdf. 

Appendix A

Commercial Compliance Studies 



\section{Appendix A}

\section{Commercial Compliance Studies}

The commercial compliances studies reviewed in this report are categorized into four main sections below: Northwest evaluations, California evaluations, other key state evaluations, and DOE ARRArelated evaluations. A short summary of each study is provided along with the citation in case additional information is desired. It should be noted that the level of detail provided in the compliance study reports varied greatly. Some reports were several hundred pages long, and where additional detail is provided in the study but was too lengthy for this report, it is so noted in the summaries below.

\section{A.1 Northwest Studies}

Popular opinion is that some of the seminal work in the area of energy code compliance evaluation has occurred in the Northwest. For that reason, studies related to the Northwest are represented in their own category in alphabetical order with most recent study first.

\section{A.1.1 Idaho, Montana, Oregon, and Washington (Ecotope 2008)}

This study looked at the baseline characteristics of the 2002-2004 nonresidential sector in four states: Idaho, Montana, Oregon, and Washington. Comparisons with the earlier 1996-1998 study were also made.

Site visits were conducted at 350 completed buildings (about $65 \%$ of the buildings contacted were recruited). Four specific building types were the focus: grocery stores, hospitals, retail establishments, and schools, as they were of particular interest to NEEA. Utilities also made enhancements to the regional sample for their own interests.

Research goals included to: generate a summary of characteristics associated with the major energyusing components of commercial buildings (HVAC, lighting, envelope, and refrigeration); assess energy code compliance for HVAC equipment, lighting, and applicable envelope components; and perform a regional assessment of energy use and estimate energy use intensities by building type within each sample. (Results of the last goal were not included in the study.) In certain circumstances, when data were not available, details were assumed to be code compliant. Energy use information was also obtained through billing releases.

\section{Client: NEEA}

Study Date: 2008

Code: the particular code against which compliance was measured varied by state, and in the analysis of individual buildings, the code for the applicable jurisdiction was used to determine compliance (codes listed below were considered to be the prevalent code during the "design window"):

a. Idaho: 2000 International Energy Conservation Code (IECC)

b. Montana: American Society of Heating, Refrigerating, and Air-Conditioning Engineers (ASHRAE) 90.1-1989

c. Oregon: 1998 state energy code (with 2001 ASHRAE equipment efficiencies)

d. Washington: 2001 state energy code 


\section{A.1.1.1 Method}

- Sample Selection: used Dodge database to select relevant buildings, developed size strata (3), picked random sample within strata, and assigned corrective weights across strata. The sample was then allocated so that each stratum represented roughly a third of the total sample. Each sample was assembled based on a $90 \%$ confidence interval, with significance criteria of $10 \%$. The Dodge data was cleansed by removing alterations, duplicates, and non-building structures, etc. Bias seems to occur most often during recruitment because of non-response or self-selection. This study had a nonresponse rate of $38 \%$, which the team thought was sufficient to minimize this bias. Overall, this study is an example of the most comprehensive sample selection approach. It covers randomizing the sample, representativeness, and non-response/self-selection. The method seems comprehensive, but not overwhelming.

- Data Gathering: included interviews with design professionals, consultation of manufacturer's literature, phone conversations with installers, and review of supplemental documentation (e.g., commissioning reports)

- Recruitment: via phone calls with building owners/operators

- Field Inspection: post-construction visits

- Lighting: on-site spot checking was used for lighting after plan review: review of major fixtures, fixture information research using operations and maintenance (O\&M) manuals, and discussions with building maintenance staff

- HVAC: data was collected on HVAC systems, including characterization information and detailed specifications. Information was also collected on space conditioning, heating fuel, cooling type, distribution system types, and basic control information. Additionally, major fans and pumps were categorized and documented. The systems were described in some detail, especially packaged or built-up, multi-zone systems. Controls and control strategies were documented when available. The auditors relied heavily on observed nameplates, O\&M manuals, and as-built equipment schedules, which formed the basis for the equipment review; efficiency information was gathered from secondary sources and manufacturer literature. Each system was described as it related to the buildings as a whole; this allowed buildings with multiple systems of different types to be categorized and weighted based on all systems present rather than just the primary system.

- Mechanical System Controls: surveyed at the building level and at the system level in multi-use buildings. Documentation sources included sequence-of-operation documents, site observations, and discussions with staff.

- Refrigeration: only reviewed significant systems (defined as those with remote compressors). Therefore, central refrigeration systems associated mainly with grocery and retail buildings and walkin refrigeration systems in other building types were the only systems included. In addition, cold storage areas that were typically part of larger warehouse buildings were reviewed, but only one was of sufficient size to be termed a cold storage system. Self-contained refrigerators and freezers were generally not included.

- Building Envelope: data from construction specifications and other documentation were used when components were unobservable in the field; where data were not otherwise available, envelope components were assumed to meet the requirements applicable to the applicable code. 
- Interviews: design professionals; interview questions are provided in the study

- Compliance Method: percentage of buildings by system

Table A.1 provides the final sample of audited buildings after participating utilities added their selections.

Table A.1. Final Sample of Audited Buildings (after Utilities)

\begin{tabular}{llllll}
\hline Building Type & ID & MT & OR & WA & Region \\
\hline Assembly & 2 & 0 & 2 & 4 & $\mathbf{8}$ \\
College & 3 & 1 & 3 & 2 & $\mathbf{9}$ \\
Schools & 11 & 2 & 24 & 30 & $\mathbf{6 7}$ \\
Grocery & 2 & 0 & 6 & 10 & $\mathbf{1 8}$ \\
Health Services & 5 & 2 & 3 & 6 & $\mathbf{1 6}$ \\
Hospital & 4 & 1 & 7 & 13 & $\mathbf{2 5}$ \\
Institution & 3 & 1 & 9 & 10 & $\mathbf{2 3}$ \\
Office & 7 & 3 & 9 & 8 & $\mathbf{2 7}$ \\
Other & 3 & 2 & 2 & 2 & $\mathbf{9}$ \\
Residential/Lodging & 0 & 1 & 6 & 11 & $\mathbf{1 8}$ \\
Restaurant/Bar & 3 & 0 & 4 & 1 & $\mathbf{8}$ \\
Retail & 15 & 8 & 23 & 32 & $\mathbf{7 8}$ \\
Warehouse & 6 & 8 & 9 & 17 & $\mathbf{4 0}$ \\
TOTAL & $\mathbf{6 4}$ & $\mathbf{2 9}$ & $\mathbf{1 0 7}$ & $\mathbf{1 4 6}$ & $\mathbf{3 4 6}$ \\
\hline
\end{tabular}

\section{A.1.1.2 Results}

- Code compliance in the 1996-1998 study topped out at 70\% for lighting and was similar for other end uses. This study showed $80 \%$ compliance with lighting and approximately $90 \%$ for building shell and other parts of the code. "In both studies, many lighting controls were improperly set up, poorly scheduled, or disabled because of occupant interactions or dissatisfaction. Approximately 25\% of the reported lighting problems were due to lighting control issues. Despite these complaints, from the point of view of energy efficiency, controls offer the best opportunity for energy savings in lighting systems."

- Since this study focused on occupied buildings, there were certain features that were unobservable, unlike previous studies. The authors noted that previous studies indicated that building components not available after occupancy did not differ significantly from compliance documentation. They felt a more "...significant issue was the obsolescence of some of the manufacturers' documentation due to the time lag between the completion of construction and the audit."

\section{A.1.2 Washington (Baylon et al. 1997)}

This baseline study focused on compliance with the 1994 Washington State Nonresidential Energy Code. The same methodology as in the 1991-1992 study was used. There were 792 buildings pulled 
from Dodge permit data; 217 buildings were recruited and ultimately 88 buildings were evaluated.

Client: Utility Code Group (utility consortium)

Study Date: 1997

Code: Washington non-residential energy code, largely based on ASHRAE 90.1-1989

Permit Dates: 1995

\section{A.1.2.1 Method}

- Sample Selection: used permit data from Dodge, selected eligible buildings, stratified by size, recruited all large buildings (over 122,000 sf), created random sample of small and medium buildings, and weighted sample based on sampling probability - a building larger than 122,000 sf was six times more likely to be selected than a small building of less than 30,000 sf.

\section{- Plan Review}

- Field Inspection: on-site visits conducted post-occupancy

- Interviews: designers, builders, and code officials; interview questions are provided in the study

- Compliance: compliance vs. non-compliance focused on three areas: building envelope, mechanical HVAC systems, and lighting. It was felt that these were the areas that could be verified and had the most energy impact.

- Building Envelope: Compliance for building envelope was assumed if the building passed the prescriptive, component performance, or energy budget approach. Theoretical heat loss calculations were performed for each building at code baseline levels and compared to the heat loss rate of the actual buildings. If the heat loss rate of the actual building was lower than that of the theoretical code heat loss rate, the building was assumed to be in compliance with the component performance requirements of the code.

- HVAC: It was determined that overall compliance did not appear to be affected by the mechanical system compliance path chosen. Simple systems had roughly the same non-compliance rate as complex systems. HVAC compliance was determined based on the key components with the most energy use, and if any of these were found out of compliance, the entire mechanical system was deemed not to comply.

- Lighting: Compliance was defined as not exceeding the lighting power allowance or failure to meet the efficiency standards in the prescriptive path.

\section{A.1.2.2 Results}

Results were $61 \%$ compliance overall based on compliance by building, by system. All criteria must be met for a building to be compliant.

Table A.2 compares the samples by system type between the 1990 study and the 1995 study. 
Table A.2. Sample Comparison Between 1990 and 1995 Studies

\begin{tabular}{lcccccc}
\hline & & & \% Weighted & $\begin{array}{c}\text { \% Area } \\
\text { Weighted } \\
\text { Sample }\end{array}$ & $\begin{array}{c}\text { \% Weighted } \\
\text { Sample }\end{array}$ & $\begin{array}{c}\text { \% Area } \\
\text { Weighted } \\
\text { Sample }\end{array}$ \\
\cline { 2 - 7 } & \multicolumn{2}{c}{ \% of Sample } & $\mathbf{1 9 9 5}$ & $\mathbf{1 9 9 5}$ & $\mathbf{1 9 9 0}$ & $\mathbf{1 9 9 0}$ \\
Envelope & $\mathbf{1 9 9 5}$ & $\mathbf{1 9 9 0}$ & 84 & 86 & 78 & 60 \\
HVAC & 84 & 80 & 87 & 80 & 74 & 74 \\
Lighting & 86 & 76 & 67 & 83 & 72 & 84 \\
Overall & 81 & 76 & 50 & 59 & 47 & 59 \\
\hline
\end{tabular}

Despite low compliance rates, buildings were more efficient than in the prior study, and authors noted the main reason for this as the current study failed buildings for relatively minor infractions (in terms of energy use).

\section{A.1.3 Oregon and Washington (Baylon et al. 1992)}

This study was one of the first full-scale compliance evaluations to be undertaken for commercial code compliance. It is the base study upon which other studies were built as noted above.

There were four main goals of the study to: 1) characterize building activity and current construction in a random sample of new commercial buildings; 2) assess code compliance in the sample through a combination of building documents review, site visits, and comparing results of code requirements; 3 ) interview design professionals and code officials to determine attitudes toward the code; and 4) review the energy code and suggest changes to make it more effective.

Client: Oregon and Washington State Departments of Energy

Study Date: 1991

Permit Dates: Oregon 4/90 - 1/91; Washington 1/90 - 1/91

Code: Buildings were evaluated based against whichever code was being enforced at the time they were permitted and built

\section{A.1.3.1 Method}

- Sample Selection: done using Dodge data; eliminated buildings that cost less than $\$ 200,000$ to construct; Washington had a sample frame of 468 buildings, and Oregon's sampling frame was 213 buildings. Fifty buildings were drawn at random from each size strata for recruitment, and additional buildings were drawn as needed based on recruitment. Buildings over 40,000 sf were considered "large", and buildings under 40,000 sf were considered "small." The final sample size in both states was 70 buildings. The authors note biases in that the Washington sample of large buildings was an over-representation of schools and under-representation of warehouses.

- Building Types: 11 building types were included: office, retail, grocery, restaurant, warehouses, school, assembly, institution, lodging, health, and other. The report provides details as to the number of buildings and square footages of the samples in each building type by state.

\section{- Plan Review}

- Field Inspection: conducted for each building 
- Interviews: building designers and code officials; interview questions are provided in the study

- Compliance: assessed in three building systems: envelope, mechanical, and lighting. Compliance was defined for each system. For example, envelope compliance was based on the allowable heat loss rate. The average heat loss for all wall components, ceiling components, and floor components was calculated and all were combined into the building's overall heat loss rate. That rate was compared to the same calculations using code requirements. Compliance was achieved when the energy code budget heat loss rate was greater than or equal to the heat loss of the designed building.

- Mechanical: compliance focused on equipment efficiency, sizing, economizers, and air transport factors. There were several items that were not reviewed, including: duct insulation, HVAC controls, service water, and simultaneous heating and cooling.

\section{A.1.3.2 Results}

- The final compliance determination was based on the on-site audit unless the building was only in the preliminary stages of construction.

- In Washington, 51\% of the buildings complied with the energy code on all building systems, and compliance for the major building systems varied between $70-80 \%$, and compliance did vary substantially by building type. The distribution of compliance was much better for large buildings than small (about half of the difference was explained by the use of the energy budget for four large buildings). Retail buildings had poor compliance due to display lighting, and warehouses also had poor compliance, usually due to reduced envelope insulation. The report also provides compliance rates by major systems and reasons why certain compliance rates were observed.

- In Oregon, 54\% of the buildings complied with the energy code on all building systems, and much the same results as in Washington were observed, with the exception of HVAC system compliance which was much improved in Oregon (95\%).

\section{A.1.4 Oregon and Washington (Baylon 1991)}

This effort was a pilot study to test the survey instruments and design procedures developed to conduct commercial building energy code compliance evaluation. Only five buildings were ultimately selected for the pilot study: in Washington (two office buildings - 3,500 and 4,100 sf, one school 106,000 sf, and a library - 21,000 sf) and in Oregon (one department store - 185,000 sf).

Client: Oregon and Washington State Departments of Energy

Study Date: 1991

Permit Dates: Oregon 4/90 - 1/91; Washington 1/90 - 1/91

Code: No specific state codes were identified in the study

\section{A.1.4.1 Method}

- Sample Selection: drew random sample of 200 buildings from Dodge stratified by building size (over and under 40,000 sf); large sample assumes attrition with expectation of evaluating 140 buildings.

- Recruitment: contacted sites based on Dodge contact information

- Building Types: office, school, library, department store 
- Plan Review: plans were available for all five buildings

- Specifications: were available for four buildings; used SCAN film data from Dodge for the fifth building

- Field Inspection: post-construction seemed to be preferred

In completed buildings, mechanical equipment and lighting fixture counts and types were verified. Type of ballast was often difficult to determine due to access. Mechanical equipment was verified by comparing nameplate data to the specifications. Insulation levels were confirmed where possible and seemed consistent with the plans.

- Interviews: architects and engineers, although answers were very general and it was difficult to get project-specific details; interview questions are provided in the study

\section{A.1.4.2 Problems}

- Code compliance information in documents varied greatly; specific equipment details were particularly problematic.

- Difference in construction stage affected items that could be verified. One office building had just broken ground and the school was under construction at the time of the pilot study.

\section{A.1.4.3 Findings}

- Barely half of the buildings complied with the energy code.

- Project documentation is difficult to obtain.

- Engineers provide criteria for compliance to architects and building departments even when this information is not included in the design.

- More valuable data on code compliance was obtained through plan review and onsite inspection than interviews.

- Prescriptive path favored over component path by architects and engineers, although none of the buildings met the code unless the component path was used.

- Lighting compliance is difficult to determine in large buildings. (In the pilot study, spot checks were done of at least $25 \%$ of the available area.) There were substantial differences between lighting specified on the plans and installed lighting. The authors speculated this could be because tenants often redesign lighting.

\section{A.1.5 Summary of Northwest Studies}

The following bullets provide an overview of the Northwest studies.

- A simpler, prescriptive compliance path is suggested as buildings were more successful with prescriptive approaches. 
- Submittals are important. They should also contain the necessary information to evaluate for code compliance, including code compliance forms, efficiency schedules for equipment and lighting, and individual equipment specifications.

- Field visits and plan review are better for gathering compliance data than are interviews. When data are missing from plan review and visits, engineers can often provide other forms of compliance evidence.

- In generating the sample, select relevant buildings, develop size strata (S,M,L) and pick random sample within each stratum.

- Soliciting participation is time consuming but critical.

- Most included on-site post-construction visits.

- Interviews were conducted with design professionals and sometimes code officials.

- A compliance evaluation metric, when given, was typically percentage of buildings/sample by system.

\section{A.2 California Studies}

This section reports on several California studies. The studies were typically produced with funding from California utility companies.

\section{A.2.1 Draft Evaluation Plan: California Statewide Codes and Standard Program (Cadmus 2012)}

The evaluation plan describes the activities for the evaluation team to undertake to verify the savings projections of the statewide California Codes and Standards program during program years 2010, 2011, and 2012. Evaluation activities and resources were focused on the Codes and Standards expected to produce the largest energy savings.

Contractor: Cadmus Group

Client: California Investor Owned Utilities (PG\&E, SDGE, SCE, SCG)

Study Date: 2012

Codes: California Title 24 2005; Title $242008^{1}$

\section{A.2.1.1 Method}

- Working Group: Use to gather expert knowledge to understand stakeholder contributions to code development and to develop estimates for naturally occurring efficiency.

- Sample Selection: Jurisdictions in Climate Zones 3 and $12^{2}$ in PG\&E service territory only using Dodge permit data. Ten renovations and 10 new construction projects to be selected based on

\footnotetext{
${ }^{1}$ The California Energy Code is Part 6 of the California Building Standards Code, which is Title 24 of the California Code of Regulations also titled "The Energy Efficiency Standards for Residential and Nonresidential Buildings."

${ }^{2}$ Note that California uses different climate zones than those used in ASHRAE Standard 90.1 and the IECC.
} 
accessibility, willingness to participate and availability of data. No expectation of randomness or representativeness.

- Recruitment: used permit data.

- Field Inspection: with a focus on as-built conditions; likely post-occupancy but unclear.

- Tools: calculated results using Energy Pro

- Data: used online tool

\section{A.2.1.2 Results}

None reported; this was a planning document only. Two ratios to be developed: as-built conditions to the 2008 code and as-built conditions to the 2005 code. The ratios are then compared to savings from naturally occurring efficiencies caused by the market rather than code.

\section{A.2.1.3 Problems}

- No successful baselines available; more field data needed.

- Limited access to permit information.

- $\quad$ Limited access to buildings.

\section{A.2.2 Codes and Standard Programs Impact Evaluation (KEMA 2010)}

This report presents the impact evaluation of the California investor owned utilities' (IOUs) statewide Codes and Standards Program for the 2006-2008 Program years. Energy savings from these programs were claimed by the IOUs. The final sample was 80 newly constructed buildings and 140 alterations within 9 building departments.

Contractor: KEMA/Cadmus

Client: California Public Utilities Commission

Study Date: 2010

Code: California Title 24-2005

\section{A.2.2.1 Method}

Compliance rates are adjusted for naturally occurring market adoption, normally occurring standards adoption, measure life and an attribution factor. This results in net program savings. The details of the adjustments were not described in the report, only the compliance rate.

- Stakeholder Survey: 10 utility staff and consultants involved with Title 24 adoption. They were asked about their sense of resource allocations for adoption.

- Sample Selection: Used utility hookup information. These data were matched to 12 unique building department permit data sets. Buildings that participated in IOU programs were eliminated. Schools, hospitals, and other buildings not subject to the permitting process were also eliminated. Buildings 
were segmented by new construction and alteration. All high-energy use buildings (top quartile) were included in the sample; remaining buildings were sampled randomly. Aerial photographs were used to determine if construction actually occurred and if a building was built on a greenfield. The final sample was 80 new construction and 140 alterations within nine building departments. Sample was considered representative of IOU service areas with the exception of San Diego Gas \& Electric. No statistical significance reported, but the sample size is thought to increase validity and reliability of the result.

- Recruitment: Used permit data to contact buildings

- Field Inspection: 81 site visits conducted. It is not clear whether these were during or postconstruction, but likely post. Non-observed items were assumed to be compliant.

\section{A.2.2.2 Results}

- Based on EnergyPro runs that determine whole-building compliance. EnergyPro calculates prescriptive compliance for the envelope, indoor lighting, HVAC, outdoor lighting. It can calculate compliance using a performance approach.

\begin{tabular}{lcc} 
Building Type & \# Buildings & Compliant Buildings \\
\hline Alterations & 4 & $25 \%$ \\
New & 26 & $61.50 \%$ \\
\hline
\end{tabular}

\section{A.2.2.3 Recommendations}

- Integrate utility demand side management programs to code and standards goals for adoption and compliance.

- Implement policies to ensure local code jurisdictions get the necessary compliance documentation.

- Whole building compliance is preferred over an individual component approach.

\section{A.2.3 Statewide Codes and Standards Market Adoption and Noncompliance Rates (Quantec 2007)}

Quantec produced this study for Southern California Edison based on permits filed between November 1, 2005, and June 2006. The site visits were conducted between July and September 2006, by Quantec field technicians. This study evaluated five specific building measures and several appliances. Compliance was based on a specific process of determination using a statistical methodology for evaluating buildings through plan review and on-site inspections.

Contractor: Quantec

Client: Southern California Edison

Study Date: 2007

Code: 2005 Title 24 


\section{A.2.3.1 Results}

Through this study, noncompliance values varied widely by measure, ranging from $28 \%$ for hardwired lighting to 100\% for nonresidential ducts (both new and retrofit). The table below provides a high-level summary of the results by building measure. The report provides further details on each building measure.

Table A.3. Summary of Building Measure Noncompliance Estimates

\begin{tabular}{ccc}
\hline Nonresidential & Estimated Noncompliance Rate & Precision of Estimate \\
\hline Lighting controls under skylights & $44 \%$ & $10 \%$ \\
Cool roofs & $50 \%$ & $3 \%$ \\
Bi-level lighting controls & $\mathrm{NA}$ & $\mathrm{NA}$ \\
Ducts in existing buildings & $100 \%$ & $2 \%$ \\
Duct testing/sealing in new buildings & $100 \%$ & $1 \%$ \\
\hline
\end{tabular}

\section{A.2.3.2 Recommendations}

In future studies, the authors recommend:

- Performance modeling to determine levels of whole-building compliance to help provide insight into the actual energy impacts of permit and process noncompliance, as well as partial compliance.

- Pinpointing and correcting flaws in the compliance chain so that energy savings predicted from the codes can be fully realized in the following areas:

- Market behavior

- Building department processes and compliance

- End-user surveys

- Comprehensive building-specific studies

\section{A.2.3.3 Compliance Scoring}

Each permit reviewed was given a score in each of the three compliance categories: process, design, and field. The scores themselves were derived from an evaluation of how close the component came to meeting the code requirement. Complete noncompliance existed when no evidence of knowledge or intent to comply with code existed (score $=1$ ). Partial compliance was given when some evidence was found of an attempt to comply with code, but compliance was incomplete (score $=0.5$ ). Full compliance existed when the measure was present and was fully documented, fully contained in the design, or installed in the building (score $=0$ ).

In order to assess the accuracy of permit scores, site visits were carried out on a sample of buildings for each measure. Scoring was done using the same methodology described for the record reviews: a building project noncompliant with code received a score of 1 and compliant projects were given a score of 0 . As with the review of permits, some measures could not be fully assessed on site, but appeared to be compliant and, therefore, received a score of 0.5. For example, a cool roof that appeared to have some 
cool roof properties (e.g. light in color) but was unable to be verified would receive a partial compliance score of 0.5. The final site visit scores were then used to update the initial compliance scores using a Bayesian statistical analysis. Finally, all noncompliance scores were weighted according to the building department using building valuation figures for 2006 and 2006. [California construction valuation figures for 2006 were for the first nine months of the year. Data were obtained from the Construction Industry Research Board.]

\section{A.2.3.4 Estimated Energy Savings Methodology}

Three key influencing factors were included:

- Initial market penetration and natural occurring market adoption

- Noncompliance rate for selected building measures

- Noncompliance rate for selected appliances (note: did not include the appliances in the summary)

In summary, the method used to estimate initial penetration and naturally occurring market adoption rates was devised specifically for this study and applied for the first time. The approach was an interactive Web-based tool that industry experts were able to modify in order to draw market adoption curves. It was unclear that the overall results were statistically valid.

\section{A.2.3.5 Sample Generation}

- Began with viewing a climate zone map of CA and identifying the larger metropolitan areas in each climate zone cluster. Building departments were selected to represent a mix of projects and climate zones across the state. Each department was contacted to explain the study and request access to the records. For commercial, the breakdown was 70 records; 48 reviewed, 37 inspected.

- Sample sizes were drawn with the goal of yielding statistically defensible results for each of the identified measures with $90 \%$ confidence $+/-10 \%$. Actual precision levels ranged from $+/-1 \%$ to $+/-$ $10 \%$, and the authors considered the sample to be statistically representative.

\section{A.2.3.6 Building Evaluation}

- Each building department was contacted, provided an explanation of the study, and access was requested to building plans and access to the building sites.

- The data were collected via a combined approach of reviewing building department records and conducting site visits at a sample of buildings to verify the reported compliance rates.

- One visit per site

\section{A.2.4 Discussion of California Studies}

\section{A.2.4.1 Recommendations}

- Focus on relating savings to utility programs.

- Better coordination between demand side management programs and codes programs. 
- More field study data is needed.

- Better code compliance documentation is needed in permit submittals.

\section{A.2.4.2 Compliance Method}

- Formed working groups to understand stakeholder contribution to code adoption.

- Sample Selection: based on utility data; largely not significant samples generated from this approach although they may achieve representativeness.

- Field Inspection: likely post-construction

- Calculate Results: used compliance tool. Whole-building metric preferred over percentage of requirements based metrics.

- Data: input data online and used Excel-based tools that were available.

\section{A.3 DOE ARRA-Related Compliance Studies}

Several compliance evaluation studies were conducted as DOE's ARRA “pilot studies” in 2010-2011 (DOE 2013). It is important to note that the main purpose of these DOE-funded studies was to use, test, and gain feedback on the compliance evaluation methodology developed by PNNL (PNNL 2010) rather than determining compliance rates in the participating states. All of the studies used the methodology, although given the short timeline, most projects did not use the methodology in its entirety. Specifics of the overall BECP methodology are not provided in the summaries below but are available in the methodology report (PNNL 2010). Pilot studies were conducted on both residential and commercial buildings, and the commercial compliance evaluation studies are summarized below.

\section{A.3.1 Georgia}

Georgia reviewed 69 new commercial buildings which combined for a total of 44 commercial building evaluations. (The BECP methodology allowed for building evaluations to be combined to form complete samples.)

Contractor: B\&F Technical Code Services; third-party

Client: Georgia Department of Community Affairs

Code: ASHRAE 90.1-2007/IECC 2009; though most buildings likely designed to ASHRAE 90.1-2004

\section{A.3.1.1 Method}

\section{- Formed Working Group}

- Performed Self-assessment: used BECP jurisdictional survey

- Sample Selection: used State Sample Generator but was inaccurate given economic downturn; buildings identified via Georgia Department of Community Affairs-sponsored working group; new construction only

- Trained Evaluators 
- Recruitment: solicited participation

- Plan Review

- Field Inspection: performed on-site visits (construction and post-construction)

- Data: input data into Score+Store

\section{A.3.1.2 Cost}

The cost of the study was $\$ 100,000$ (average $\$ 2,273 /$ building).

\section{A.3.1.3 Results}

The study reported $80 \%$ compliance overall by percentage of requirements met.

\section{A.3.2 Wisconsin}

Wisconsin evaluated 44 new commercial buildings (28 small, 10 medium, four large, and two extralarge). Because the state's Buildings and Safety Division is responsible for enforcing the code statewide, samples were chosen using the existing construction database and were evaluated by state inspectors.

The success of Wisconsin's pilot study is attributed to the fact that no building plan is approved unless it is accompanied by a COMcheck or other similar calculation showing that the building, as designed, meets the code. Based on the size, a few projects combined several inspections into one, and in some cases several inspections were required to complete just one phase.

Contractor: NA; self-administered evaluation by WI Safety and Buildings Division - second-party Client: NA

Code: ASHRAE 90.1-2007/2009 IECC

\section{A.3.2.1 Method}

- Sample Selection: used State Sample Generator combined with state database and via inspectors; stratified by size; and intended to be random.

- Field Inspection: on-site visits (mostly during construction). State inspectors attempted to make five separate inspections: after the footings and foundations (or basement walls) were poured; when the slab was partly poured; after the framing and insulation was in place; when the fenestration was installed and the interior finish material was being installed; and when lighting and mechanical equipment were in place and the building was almost ready for occupancy.

- COMcheck: the reviewers ran their own COMcheck reports based on either the 2009 IECC or ASHRAE 90.1-2007 (depending on which one was originally used) [this was not part of the BECP methodology]

- Data: input data into Score+Store 


\section{A.3.2.2 Cost}

The cost of the study was $\$ 143,000$ (average $\$ 3,250 /$ building).

\section{A.3.2.3 Results}

Overall results were 95\% compliance by percentage of requirements met.

\section{A.3.3 Utah}

Utah conducted a study in two phases. The Phase 1 study evaluated 16 new residential, 1 residential remodel, 9 new commercial buildings, and 1 commercial remodel against the 2006 IECC and

ASHRAE/IESNA 90.1-2007/2009 IECC, respectively.

Contractor: Colorado Code Consulting; third-party

Client: Utah Department of Facility Construction Management

Code: 2009 IECC

\section{A.3.3.1 Method}

- Sample Selection: used State Sample Generator

- Performed Self-assessment: used BECP jurisdictional survey

- Plan Review

- Field Inspection

- Data: input data into Score+Store

\section{A.3.3.2 Cost}

The total cost of Phase 1 of the study (including both residential and commercial buildings was $\$ 89,000$ ), but the costs were not separated out, so an average cost per building was not computed.

\section{A.3.3.3 Results}

Results were not reported for this phase of the study. In keeping with the educational nature of Phase 1 , the evaluators felt it was important to allow builders to correct the non-compliant issues before proceeding, so determination of a true compliance rate was not possible.

\section{A.3.4 Northwest Lighting Study}

For the Northwest Commercial Lighting Study (Washington, Oregon, Idaho, and Montana), plans were reviewed for 91 commercial buildings to evaluate code lighting requirements, and field inspections were conducted on 29 buildings. The study attempted to assess: 1) if sufficient data were included in the plans to determine whether the design met the applicable code; and if so 2) whether or not the buildings actually met the code via a visual inspection of those buildings. Ninety-one plans were reviewed and 29 buildings were visually inspected. 
Contractor: Lighting Design Lab and two independent lighting designers

Client: NEEA

Code: Varied by state (Washington State Energy Code 2009 for WA; 2011 Oregon Energy Efficiency Specialty Code for OR; and 2009 IECC for ID and MT)

\section{A.3.4.1 Method}

- Sample Selection: used State Sample Generator but then included only office and retail building types (5,000 sf or larger) since both use large amounts of lighting and represent a significant amount of square footage in the region. Due to the difficulty in identifying specific projects, the randomness of the sample is highly questionable.

- Building Type: office and retail

- Plan Review: project records were obtained by searching project files one-by-one

- Documentation: in-person visits to jurisdictions were found to be much more effective than phone or email requests

- Field Inspection: conducted post-occupancy

- Compliance: plan review observations were evaluated against the lighting power density (LPD, calculated in watts/sf) and lighting control requirements of the local energy code enforced in each of the nine municipalities (either the current or previous adopted version of each local code was allowed)

\section{A.3.4.2 Cost}

The cost of the study was $\$ 70,000$.

\section{A.3.4.3 Results}

- The commercial lighting evaluation study determined that both lighting designers and local code officials lack proficiency in the LPD calculations and lighting control requirements of their local energy code.

- A lighting study can be conducted post-construction, but still be useful in determining trends in compliance issues and identifying the training needs of local jurisdictions.

- Information acquisition was the most time consuming aspect of this project.

\section{A.3.5 Northwest Jurisdictional Survey}

The Northwest Jurisdictional Survey Study (Washington, Oregon, Idaho, and Montana) implemented a survey approach to determine current residential and commercial data collection, documentation, and storage practices and identify opportunities for improvement.

Contractor: NA

Client: NEEA

Code: NA 


\section{A.3.5.1 Method}

- NEEA used the BECP jurisdictional survey to collect data regarding actual enforcement practices in jurisdictions, and coordinated with four state-specific entities to distribute the survey to local building departments: 1) Washington State University Energy Extension Program; 2) Oregon Building Codes Division; 3) Idaho Association of Building Officials (via a contractor); and 4) Montana Department of Environmental Quality.

- An attempt was made to select jurisdictions that were representative of each state as a whole (based on demographic characteristics such as number of permits issued per year, number of building department staff, and mix of buildings permitted).

- The NEEA study was exploratory and did not attempt to produce statistically valid results.

- Surveys were administered differently in each state: mail-in, on-line, and in-person. In some cases, surveys were supplemented by interviews, plan reviews, and construction site visits.

\section{A.3.5.2 Cost}

This study cost $\$ 25,000$.

\section{A.3.5.3 Results}

- This study reported that virtually all jurisdictions in the Northwest require energy code documentation with plan submittals.

- Idaho jurisdictions also specifically mentioned requiring HVAC load calculations.

- All respondents in Washington, Oregon, and Montana stated that commercial records are kept for seven years or more, while some Idaho jurisdictions keep residential records for less time (one to five years).

- When asked what information is typically missing that prevents determination of commercial building energy code compliance, 52 responses referred to missing information on the building plans, and five Oregon jurisdictions noted that COMcheck reports were missing.

\section{A.3.6 Summary of DOE ARRA-related Compliance Studies}

In summary, variations of the BECP methodology were used to complete the pilot studies.

- States need compliance experts, maybe even state-level positions.

- Submittals should include more compliance information.

- The energy code is a low priority for many.

- Working groups were used to recruit buildings and to train/engage local officials.

- Sample Selection: Some states attempted randomization and representativeness, but details were not always reported. In at least one study, a convenience sample was used. There was no discussion of dealing with self-selection bias or attrition.

- Field Inspection: Difficulty with access and timing were noted. 
- The compliance metric used most often was percentage of requirements met.

- Compliance metrics were above $80 \%$ in most cases.

\section{A.4 Key State Compliance Studies}

The next studies summarized were identified using references listed in other studies, a review of recent ACEEE Summer Study topics, and through a request sent to the REEOs. These key studies are presented alphabetically by state below. In some cases, these studies were conducted with ARRA funds but not as part of DOE's pilot studies reported above.

\section{A.4.1 Illinois (APEC 2011)}

Illinois conducted plan reviews and field inspections to measure the baseline compliance rate for new residential and commercial buildings against the 2009 IECC. Ten new commercial buildings (3 large, 3 medium, and 4 small) were included in the sample.

The goals of the project included to: 1) test the BECP methodology, 2) conduct preliminary assessment of existing compliance rates, and 3) identify obstacles to code compliance that could be addressed through training, outreach, and technical assistance

Contractor: Association of Professional Energy Consultants, Inc.

Client: MEEA and Department of Commerce and Economic Opportunity

Study Date: 2011

Code: 2009 IECC

\section{A.4.1.1 Method}

This study used the BECP methodology.

- Sample Selection: used State Sample Generator was used for random sample within 35 jurisdictions, based on permits representing 2008-2009 construction starts

- Performed Self-assessment: used BECP jurisdictional survey

\section{- Plan Review}

- Field Inspection: performed limited on-site visits and used team members familiar with and known to the Illinois code enforcement community to help gain access

- Interviews: jurisdictions

- Data: input data into Score+Store

- Compliance Method: percentage of buildings pass, but no result was given as sample size was too small to be statistically valid

\section{A.4.1.2 Cost}

The study cost $\$ 198,000$ (average $\$ 19,800$ each building). 


\section{A.4.1.3 Results}

No result was given as the sample size was too small to be statistically valid. However, the study reported the compliance methods used by the projects as prescriptive (seven projects) and three trade-off (COMcheck). The most common infractions included: 1) heating and cooling system sizes/types/ capacities observed in the field did not match submitted HVAC load calculations; 2) slab-edge insulation R-values were not appropriate; and 3) slab-edge insulation was not installed in accordance with the code requirements in the manufacturer's instructions.

\section{A.4.2 Illinois (Elnecave et al. 2014)}

This study describes a method for attributing energy savings from energy code compliance to utility programs. No actual data were gathered or evaluated, although a baseline compliance rate was established. This study includes both residential and commercial, and the costs were not separated.

Contractor: MEEA

Client: Department of Commerce and Economic Opportunity

Study Date: 2014

Code: 2012 IECC

\section{A.4.2.1 Method}

- Stakeholder outreach (mostly IOUs)

- Establish baseline compliance rate: use modified version of BECP methodology; generate random sample; and use Score+Store. Note: establishing the compliance baseline occurred simultaneously with the development of the code compliance enhancement plan. Consequently, the baseline compliance rates, for determining potential savings, attribution and allocation were assumed. The actual baseline compliance rate does not matter as the project aims to measure the relative improvement from the base compliance rate to the final measured compliance rate. (Mathematically, a $5 \%$ point improvement represents the same savings whether the baseline compliance rate starts at $40 \%, 50 \%$, etc.)

- Complete checklist during construction

- Develop and compare as-built to compliant energy model for each building

- Apply savings across construction rates in IOU service areas

- Compliance Method: percentage of buildings pass/fail

\section{A.4.2.2 Cost}

The total cost of the program is $\$ 3,413,000$, but this includes $\$ 2,000,000$ for rebates, both residential and commercial. The report breaks down program costs into categories. 


\section{A.4.2.3 Determining Cost Effectiveness}

IL energy efficiency programs require a lifecycle benefit/cost analysis be calculated for every program implemented using IL ratepayer funds. The metric used to determine cost-effectiveness is the Total Resource Cost test (TRC) and has to be greater than 1.0. The TRC results were shown to be cost effective generating a ratio of aggregated benefits over aggregated costs $>4$.

\section{A.4.2.4 Notes}

To determine the potential savings from the program itself and energy savings the utilities can take, it was assumed that the baseline compliance rate in IL is 70 percent (based on a voluntary survey conducted by DCEO). A further assumption was made that this meant that 70 percent of all new construction (both res and com) is fully code compliant and 30 percent of the new construction if fully non-compliant. Therefore, only 30 percent of buildings that are non-compliant are the target market for this program. Another assumption was that the energy usage of non-compliant building is 143 percent of that of the code compliant building of similar characteristics. And on average the program efforts will increase code compliance by 10 percentage points and by the end of the program cycle the statewide compliance of new construction will be raised from 70 to 80 percent. (This approach was used to develop the initial estimate because of lack of baseline code compliance. A code compliance study is currently being done.) Savings claimed from this methodology will be deemed savings until the measure and evaluation study is completed.

Energy savings were calculated from construction estimates multiplied by energy savings for a utility area. Commercial energy savings were parceled out by building type using PNNL modeling data for commercial buildings and construction estimates were found using Reed construction data. Energy Savings per Square foot $\mathrm{x}$ statewide new construction square feet = statewide energy savings

\section{A.5 Indiana (Britt Makela Group 2005)}

The study was to assess current construction practices and how it compared to the 2000 IECC, but due to extended grant time, the comparison was modified to the 2003 IECC. At the time of the study, Indiana did not have a commercial energy code in effect. The study did not provide overall building compliance (e.g., an overall compliance result was not provided for the 55 buildings in the study). Office, restaurant and retail occupancies comprised $44 \%$ of the sample; multi-occupancy type buildings were also selected. The study provided a summary of the construction details (e.g., average wall types, floor types, and roof types with the average range of insulation R-values, glazing percentages and window and door types), but not overall compliance or individual compliance per building.

Contractor: ICC/Britt Makela Group

Client: Indiana Department of Fire and Building Services (IDFBS)

Study Date: 2005

Code: 2003 IECC 


\section{A.5.1 Method}

- Sample Selection: IDFBS assisted with the selection of projects based on those that were submitted to IDFBS for review. Also, projects were selected by plans that had adequate information to determine compliance. This suggests that the sample was not statistically representative.

- Building Types: to provide a broad assessment of commercial construction practices, every effort was made to include a broad range of occupancies that represented typical construction in Indiana. The study included both single and multiple occupancy buildings. Forty-four percent of the sample size was office, restaurant, and retail occupancies.

- Compliance Method: COMcheck was used as the primary tool for compliance evaluation. The majority of projects were entered into COMcheck, and the reports and checklists were used for plan reviews and field inspections. The checklists used by the inspectors did not require that every energy feature in the buildings be inspected.

- Training: a two-day training was held for IDFBS state inspectors

- Field Inspection: one site visit was conducted per building; only 35 of the 55 buildings were inspected

Assumptions were used for the following:

- Envelope

○ Default values from 90.1-1989 were used for missing fenestration and door data

- Some of the plans included no information on wall insulation R-value and most plans were for metal buildings. An assumption of R-11 insulation installed between metal framing was assumed.

- Slab edge insulation - insulation could not be verified for most projects, therefore, based on plan details, a slab with insulation stopping under the slab was counted as an uninsulated slab.

- HVAC

- Missing mechanical system sizing - used rule of thumb of $400 \mathrm{sf}$ of conditioned floor area per ton of cooling to determine approximate equipment capacity; tonnage was divided by the total number of cooling systems shown on the plans to approximate system capacities. Heating system capacities were not considered unless the building used a boiler.

- Economizers were only documented if called out on the plans and verified in the field

- Temperature controls were only documented if called out on the plans and verified in the field (no reporting was provided on temperature controls under the findings portion in the study)

- Lighting

○ Lighting power allowances - no additional credit was given for display lighting as allowed by IECC

- Lamp ballast type - electronic ballasts were assumed for all HID and fluorescent fixtures

- Watts/fixture - if wattage for the fixture was not included on the plans, default wattage was selected from the software 


\section{A.5.2 Problems}

- Access (field inspections) for all of the projects

- Phases of construction hindered on-site inspections (only one on-site inspection was performed on the buildings that were accessible at the time of this study)

- Compliance for the building envelope could not be determined for a portion of the projects because the R-value for the proposed wall assembly was lower than the minimum values allowed by COMcheck. The values were based on ASHRAE 90.1-1989 requirements for the building envelope.

- Similar issue with fenestration in which no data was provided to enter into COMcheck.

\section{A.5.3 Results}

- Two buildings failed envelope by $-6 \%$ and $-8 \%$.

- Three buildings failed code requirement for glazing percentages between $10-25 \%$ with margins of $1 \%,-11 \%$, and $-0.1 \%$.

- Forty buildings were reviewed for lighting, but fixture wattage was not provided in the lighting schedule for several plans. Only one project for single occupancies passed the LPD allowed vs. actual watts/sf (grocery); all others failed ranging from $-4 \%$ to over $-50 \%$. Multiple occupancies on average passed compliance for actual vs. allowed LPDs (office and restaurant occupancies failed). Lighting levels were higher than allowed for the majority of projects.

- Twenty-six projects complied with independent lighting controls; three projects installed bi-level switching. Twenty-four out of the 26 projects exceeded the 45 lumens/watt min. req. for exterior lighting. The designation of an exterior lighting control, either a photocell or a time clock with seasonal adjustments, was found on 13 of the projects.

- Forty-three buildings were reviewed for HVAC, and only two buildings were classified as having complex systems. HVAC load calculations were not found for any of the projects.

\section{A.6 Massachusetts (KEMA 2012)}

A total of 75 commercial buildings were evaluated: 19 small ( $<=25,000 \mathrm{sf}), 17$ medium $(>25,000 \mathrm{sf}$ to 60,000 sf), 32 large ( $>60,000$ sf to 250,000 sf), and 7 extra-large ( $>250,000$ sf).

\section{Contractor: KEMA}

Client: Massachusetts Energy Efficiency Program Administrators

Study Date: 2012

Code: 2006 and 2009 IECC

\section{A.6.1 Method}

- Used BECP checklists

- Sample Selection: generated random sample from Dodge data, 3 years of data used, weighted by size

\section{- Plan Review}


- Complete Checklist: post-construction

- Field Inspection: develop and compare as-built to compliant energy model for each building

- Interviews: with market actors (program administrators, building code officials, selected wholesale/retail suppliers, and members of the design community)

- Attribution: apply savings across construction rates in IOU service areas

- Compliance Method: 83\% buildings pass (weighted by building size); no building was fully compliant

\section{A.6.2 Results}

- No buildings were $100 \%$ compliant. On average, buildings were $20 \%$ above or $20 \%$ below code.

- Compliance better in larger buildings

- Training for market actors is important

\section{A.7 Nebraska (Britt Makela Group 2014)}

The purpose of the study was to assess compliance with the commercial provisions of the 2009 IECC. The BECP State Sample Generator was used for a total sample size of 38 buildings in 11 jurisdictions. Both quantitative and qualitative analyses were conducted. Buildings selected were representative of the majority of commercial construction in Nebraska: low-rise commercial no more than two stories in height, with single-zone HVAC equipment. Fifteen different occupancy types were included, with the majority being education and retail. The report provides a listing by building type.

Contractor: Britt Makela Group

Client: Nebraska Energy Office

Study Date: 2014

Code: 2009 IECC

\section{A.7.1 Method}

- Used BECP methodology and checklist, but only included Tier 1 and Tier 2 items.

- Sample Selection: used State Sample Generator; contacted 11 jurisdictions; stratified by size and geography

- Plan Review: occurred at building departments, and COMcheck documentation was also obtained. Data collectors surveyed the jurisdictions and identified these concerns: lack of training as well as the lack of a standard method to conduct plan review and inspections.

- Field Inspection: on-site visits occurred during construction, and pictures were taken to help document compliance. Lighting was generally not observable because final lighting systems had yet to be installed.

- Interviews: code officials interviews were conducted 
- Data: Score +Store was used to determine compliance rates for each building. When no additional documentation was obtainable, it was assumed the building used the prescriptive approach to comply and was compared against the prescriptive requirements checklist.

\section{A.7.2 Results}

- Overall statewide compliance was $83.2 \%$, and jurisdictional compliance ranged from $43.9 \%$ to $97.2 \%$.

- Area-weighted compliance rates were generated by occupancy type to determine if there were particular occupancy type issues. Compliance rates ranged from $63.83 \%$ for office/warehouse to 98.93\% for warehouse/storage.

- Common issues found by category (e.g., plan review and energy code documentation) are included in the report.

\section{A.8 New York (VEIC 2012)}

The main activity of this study was plan review and on-site inspections of 26 commercial properties using the suggested BECP methodology to test energy code compliance. Nine projects were under construction and the rest were completed and occupied. The study included case studies of eight of the evaluated commercial buildings. The case studies included interviews with code officials, architects, engineers, and contractors associated with the construction of these eight buildings. Additional details of the results of the interviews are available in the report. It should be noted that a short summary of this project was included in DOE's final pilot study report (DOE 2013) because it used the BECP methodology and provided feedback to PNNL, but is reported separately here as it was not funded as a DOE pilot study.

Contractor: Vermont Energy Investment Corporation; third-party

Client: NYSERDA

Study Date: 2012 (report updated in 2014)

Code: ASHRAE 90.1-2004 (22 buildings); ASHRAE 90.1-2007 (4 buildings)

\section{A.8.1 Method}

- Multiple evaluation approaches were used, including: the BECP methodology; and compliance using the ASHRAE 90.1 Energy Cost Budget in eQuest was modeled using composite models representing typical features of the buildings in the sample.

- Three composite buildings were modeled with the aggregated components of each sampled building in each building size: "small," "medium," and "large." A second iteration of each building was modeled with the composite building system efficiencies set to $100 \%$ code requirements in order to establish the energy consumption of the baseline building. Lost savings were calculated by running modeling iterations on each $100 \%$ code compliant building against the components that were below code levels in the composite building. These lost savings represent the value of energy savings that can be realized by improved code compliance.

- Results: The "small" composite building was not in compliance; the "medium" and "large" composites complied. 
- Field Inspection: only one site visit per building was conducted, which limited the items that could be confirmed on the BECP checklists.

- Sample Selection: used the Sample Generator to draw from five representative jurisdictions. Randomly selected statistically valid sample of permits, but this over-reports mid/large building; Leadership in Energy and Environmental Design (LEED) was excluded; 26 buildings total. The sampling approach appeared to be valid across the population of the state. However, the sample of buildings drawn did not represent a statistically valid sample of commercial new construction in New York.

- Recruitment: a letter was sent to 153 commercial buildings asking for their participation in the study. An incentive of $\$ 150$ was offered for participation, but ultimately only two out of the 26 sites requested this inducement. This letter, however, proved to be instrumental in that eight building owners contacted the team themselves, and all building owners subsequently called on for participation knew of the project and were prepared to discuss it. An email was also sent to the code officials in the five identified counties for their participation. Overall, recruitment with building owners and code officials was very time consuming.

\section{- Plan Review}

\section{- Energy Simulation}

- Interviews: surveys and interviews with key stakeholders

- Data: Input data into Score+Store

- Building Envelope: compliance was difficult to inspect, as most buildings the team used the design envelope information to determine compliance. This is likely to underestimate the savings associated with improving building envelope design and construction to the levels required by code.

\section{A.8.2 Results}

- Building access was very difficult, even though a small monetary incentive (\$150) was provided. The team resorted to using tax rolls, property sales, and Google searches to help identify buildings, but in the end, a self-selection bias was introduced.

- $85 \%$ compliance overall by percentage of requirements met (statistically significant). There were lower compliance rates for smaller buildings (less than 25,000 sf) of 77\% compared to medium buildings (25,000 sf - 60,000 sf) with 85\%, and larger buildings (over 60,000 sf) at 85\%. [However, the sample size was small (26 buildings) and this result was not supported by the combined data from the Georgia and Wisconsin DOE pilot studies.]

- Individual buildings were not evaluated to cover all requirements since only one on-site inspection was done and not all of the checklist items could be evaluated in the field. Therefore, compliance per building could not be shown.

- COMcheck reports were found in the code offices for six buildings, or $23 \%$ of the total sample. Compliance documentation as required in the PNNL checklist was rarely available for projects in the sample.

- Compliance levels were generally consistent by building size between the upstate and downstate sample populations. 
- In medium and large buildings which required controls strategies, such as automatic lighting control, domestic hot water recirculation control, demand control ventilation, etc., these were not typically implemented in accordance with code. These controls strategies were not captured in prescriptive compliance evaluations that found lighting to be compliant but were captured in the suggested PNNL protocol and in the composite models.

- When technical compliance of energy efficiency levels are evaluated using the Prescriptive/Trade-Off method, compliance was determined on a pass/fail basis and was seen to vary widely across all three main building systems (HVAC, lighting, and envelope) and across all building sizes. A fairly similar percentage of buildings fail due to envelope, HVAC and lighting system non-compliance (30\% fail due to envelope non-compliance, 28\% due to HVAC non-compliance and 19\% due to lighting noncompliance). Out of the sampled buildings, $15 \%$ failed on non-compliance of two out of the three system types and none failed on all three system types. This indicates that there are deficiencies in the installed levels of efficiency relative to code requirements in all building components and equipment.

- Problematic areas include: slab insulation, interior foundation wall insulation, roof and wall insulation, lighting and HVAC efficiency and controls, air infiltration and duct leakage rates and cooling system sizing. The impact of these non-complying components (modeled in eQuest using composite commercial buildings) results is about $\$ 8.8$ million of annual lost energy savings and at least \$880 million over a 20-year period. At higher 2009 IECC code levels, this lost savings will be even greater.

\section{A.9 Vermont (Navigant 2012)}

It should be noted that a short summary of this project was included in DOE's final pilot study report (DOE 2013) because it used the BECP methodology and feedback was provided to PNNL, but it is reported separately here as it was not funded as a DOE pilot study.

Contractor: Navigant; third-party

Client: Vermont Department of Public Service

Study Date: January 2012 to August 2012

Code: 2005 Commercial Building Energy Standards

\section{A.9.1 Method}

- Formed Working Group

- Performed Self-assessment: used BECP jurisdictional survey

- Sample Selection: drew sample from data from state and utility databases; representative (geography, type, size, new construction or renovation) and random.

- Field Inspection: post-construction; used compliance checklists modified for post-construction inspections

- Data: input data into Score+Store 


\section{A.9.1.1 Results}

The overall compliance rate was $88 \%$ by percentage of requirements met with a $90 / 10$ confidence (statistically significant).

\section{A.10 Summary of Key Studies}

In summary, many of the key studies did field inspections post-occupancy. There are a few studies that were not clear about whether the visits were during or post-construction. However, these studies focused on as-built conditions, which suggests post-construction visits.

- States were able to show compliance rates above $80 \%$ in many cases; though these metrics may not have been based on appropriate samples.

- Statistical significance was often a problem for these studies.

- There is a philosophical divide on whether a percentage of requirements or a percentage of buildings approach is best.

- A compliance rate metric that can be translated into energy savings attributable to programs may be of interest to utilities and is of interest to DOE.

- More than one study reported using energy simulation.

- Most studies focused on new construction. Most experts agree that there are significant savings opportunities associated with renovations, however, these projects are harder to find data about and to visit.

- Many of the studies commented on the importance of complete submittals that show compliancerelated information. Additionally, the same submittal should be used for plan review and inspection.

- Several of the studies commented on the need for state-level compliance experts. Training and education of local officials were also seen as important. 

Appendix B

Other Methodologies and Studies 



\section{Appendix B}

\section{Other Methodologies and Studies}

This appendix covers two sources that offered additional compliance methodologies rather than actual compliance studies. In addition, short summaries of a few studies that were determined to not be relevant to the literature review are included here for completeness.

\section{B.1 Other Methodologies}

Two sources focused on possible methodologies regarding compliance evaluation in commercial buildings. The first was produced in the mid-1990s (Ecotope 1995) and the second in 2013 (Cadmus 2013), with a focus on attribution of savings.

\section{B.1.1 Ecotope 1995}

Contractor: Ecotope

Study Date: 1995

Code: Washington State Nonresidential Energy Code

Client: Utility Code Group

This source describes code compliance and enforcement responsibilities. Findings are based on interviews with participants in the code development process, a 1992 review of commercial building permits, and contractor's professional judgment.

\section{B.1.1.1 Recommendations}

- Code compliance forms, efficiency schedules for equipment and lighting, and individual equipment specs to be included in submittals. Examiner and inspectors to use same set of drawings and specs.

- All permit documentation should be associated with drawings so that inspectors can refer to it when onsite.

- Ensure that building officials have legal authority to request relevant documentation from the design team.

- Special plan examiners and inspectors used if a system or component is beyond expertise of plan examiner or inspector using submittal.

\section{B.1.2 ACEEE - Attributing Building Energy Code Savings to Energy Efficiency Programs (Cadmus 2013)}

Contractor: Cadmus Group

Study Date: 2013

Code: All States 


\section{B.1.2.1 Overview}

This is an interesting and lengthy study that focuses on attribution of savings by utilities resulting from energy code programs. Based on energy savings achieved, program administrator programs would receive incentives much how other resource acquisitions programs do.

This document provides four big ideas of use to commercial code compliance.

1. A model for energy code evaluation and attribution to utility programs

This model segments the savings from code compliance by:

A: each utility program

B: natural market efficiencies

C: and contributions from other markets actors.

$\mathrm{A}+\mathrm{B}+\mathrm{C}=$ gross energy savings realized through compliance

Any one of the three alone represents a kind of net energy savings

There are always lost savings due to non-compliance. Losses can also be quantified.

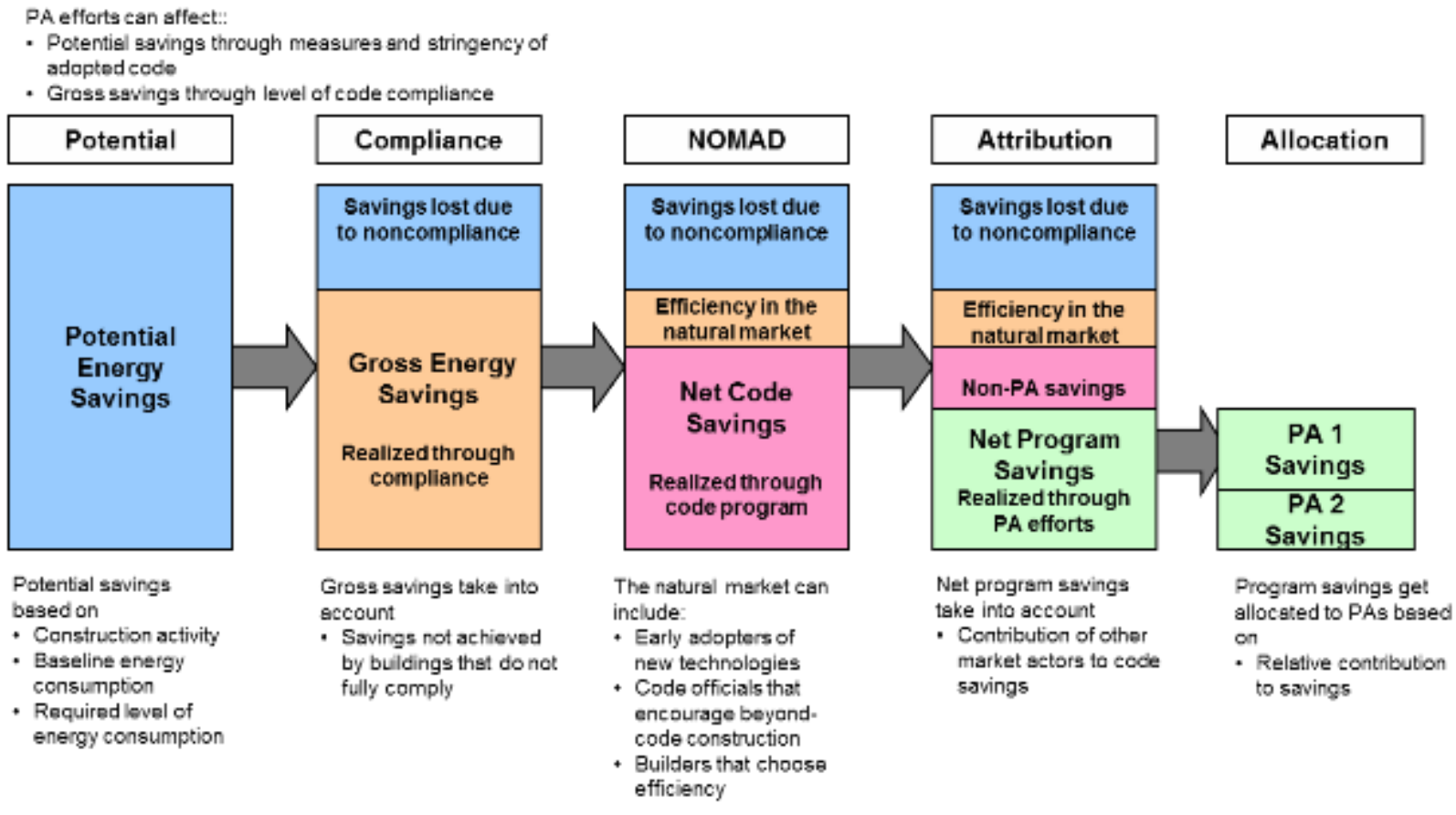

Figure B.1. General Model of Energy Code Evaluation and Attribution

2. The steps for evaluating and attributing code compliance savings
A. Measure compliance before and after an intervention
B. Calculate the savings associated with the change
C. Estimate the percentage of change attributable to the intervention

3. Categories for determining 'gross savings' 
For the authors, the distinction lies in whether the approach is primarily concerned with regulatory compliance or energy consumption resulting from compliance. The document describes the pros and cons of each approach.

\section{Direct Empirical}

Modelling: An as-built building to a reference model

Direct Billing: Compare energy bills in new and legacy code buildings

\section{Indirect Estimation}

BECP checklist

\section{Expert Judgment}

Perhaps using the Delphi method

4. Strategy Matrix for Developing Code Programs

This matrix categorizes states in relation to policy conditions. A state's placement within the matrix suggests the strategic engagement needed to improve that state's programs. The matrix could be used to inform the education and/or training portions of a compliance evaluation.

\section{B.1.2.2 Compliance Metric}

The Cadmus study's final metric is energy, though a compliance metric is required to derived the energy savings metric. A whole-building compliance metric is also supported. Two of the four savings estimating approaches offered by Cadmus require site visits. These are also the approaches they consider the most accurate. The cooperation of local code enforcement departments would likely be necessary to achieve visits. 
Table B.1. Strategy Matrix for Developing Code Programs

\begin{tabular}{|c|c|c|c|c|c|c|c|c|c|}
\hline \multirow{2}{*}{\multicolumn{2}{|c|}{$\begin{array}{l}\text { Energy- } \\
\text { Efficiency } \\
\text { Policy } \\
\text { Condition }\end{array}$}} & \multicolumn{2}{|c|}{ Does state code exist? } & \multicolumn{2}{|c|}{$\begin{array}{c}\text { Does local code } \\
\text { exist? }\end{array}$} & \multicolumn{3}{|c|}{ Who enforces code? } & \multirow{2}{*}{$\begin{array}{l}\text { Row } \\
\text { No. }\end{array}$} \\
\hline & & Yes & No & Yes & No & Local & State & $\begin{array}{c}\text { Not } \\
\text { enforced }\end{array}$ & \\
\hline \multirow[t]{2}{*}{$\begin{array}{l}\text { 1. Are there } \\
\text { energy- } \\
\text { efficiency } \\
\text { goals and/or } \\
\text { incentives } \\
\text { for PAs? }\end{array}$} & Yes & $\begin{array}{l}\text { CA, CT, GA, } \\
\text { IL, IA, MD, } \\
\text { MA, MN, } \\
\text { NH, } \\
\text { NY, OH, } \\
\text { OR, RI, } \\
\text { VT, WA }\end{array}$ & $\begin{array}{l}\mathrm{AZ} \\
\mathrm{CO}\end{array}$ & $\begin{array}{l}\text { AZ, } \\
\text { CA, } \\
\text { CO, IL, } \\
\text { MD, } \\
\text { MA, } \\
\text { NY }\end{array}$ & $\begin{array}{l}\text { CT, GA, } \\
\text { IA, MN, } \\
\text { NH, OH, } \\
\text { OR, RI, } \\
\text { VT, WA }\end{array}$ & $\begin{array}{l}\text { AZ, CA, } \\
\text { CO, } \\
\text { CT, GA, IL, } \\
\text { IA, } \\
\text { MD, MA, } \\
\text { MN, } \\
\text { NH, NY, } \\
\text { OH, OR, } \\
\text { RI, VT, } \\
\text { WA }\end{array}$ & $\begin{array}{l}\text { GA, IA, } \\
\text { NH, OH, } \\
\text { OR, VT, } \\
\text { WA }\end{array}$ & $\mathrm{MN}^{*}$ & 1 \\
\hline & No & & & & & & & & 2 \\
\hline \multirow{2}{*}{$\begin{array}{l}\text { 2. Do code } \\
\text { savings count } \\
\text { towards an } \\
\text { energy } \\
\text { efficiency goal? }\end{array}$} & Yes & $\begin{array}{l}\text { CA, NY, } \\
\text { OR, RI, } \\
\text { WA }\end{array}$ & & $\begin{array}{l}\text { AZ, } \\
\text { CA, } \\
\text { NY }\end{array}$ & & $\begin{array}{l}\text { AZ, CA, } \\
\text { NY, OR, } \\
\text { WA }\end{array}$ & OR, WA & & 3 \\
\hline & No & $\begin{array}{l}\text { CT, GA, IL, } \\
\text { IA, } \\
\text { MA, MD, } \\
\text { MN, NH, } \\
\text { OH, VT }\end{array}$ & & $\begin{array}{l}\text { CO, } \\
\text { IL, } \\
\text { MA, } \\
\text { MD }\end{array}$ & & $\begin{array}{l}\text { CO, CT, } \\
\text { GA, IL, } \\
\text { IA, MA, } \\
\text { MD, } \\
\text { MN, NH, } \\
\text { OH, RI, } \\
\text { VT }\end{array}$ & $\begin{array}{l}\text { GA, IA, } \\
\text { NH, } \\
\text { OH, VT }\end{array}$ & MN & 4 \\
\hline \multirow[t]{2}{*}{$\begin{array}{l}\text { 3. Does a } \\
\text { quantification } \\
\text { method exist? }\end{array}$} & Yes & $\begin{array}{l}\text { CA, NY, } \\
\text { OR, RI, } \\
\text { WA }\end{array}$ & & $\begin{array}{l}\text { AZ, } \\
\text { CA, } \\
\text { NY }\end{array}$ & & $\begin{array}{l}\text { AZ, CA, } \\
\text { NY, OR, } \\
\text { WA }\end{array}$ & OR, WA & & 5 \\
\hline & No & & & & & & & & 6 \\
\hline \multirow{2}{*}{$\begin{array}{l}4 . \text { Does a } \\
\text { method exist to } \\
\text { attribute } \\
\text { savings to PAs? }\end{array}$} & Yes & $\begin{array}{l}\text { CA, NY, } \\
\text { OR, RI, } \\
\text { WA }\end{array}$ & & $\begin{array}{l}\text { AZ, } \\
\text { CA, } \\
\text { NY }\end{array}$ & & $\begin{array}{l}\text { AZ, CA, } \\
\text { NY, OR, } \\
\text { WA }\end{array}$ & OR, WA & & 7 \\
\hline & No & & & & & & & & 8 \\
\hline \multirow{2}{*}{$\begin{array}{l}\text {. Is a } \\
\text { change in } \\
\text { code } \\
\text { compliance } \\
\text { counted? }\end{array}$} & Yes & RI & & & & & & & 9 \\
\hline & No & $\begin{array}{l}\text { CA, NY, } \\
\text { OR, WA }\end{array}$ & & $\begin{array}{l}\text { AZ, } \\
\text { CA, } \\
\text { NY }\end{array}$ & & $\begin{array}{l}\text { AZ, CA, } \\
\text { NY, OR, } \\
\text { WA }\end{array}$ & OR, WA & & 10 \\
\hline
\end{tabular}

\section{B.2 Other Studies}

There were three other studies that were reviewed but found to not be applicable to this literature review. Short summaries and citations are included in this section for completeness.

\section{B.2.1 Heschong Mahone Group (HMG) 2009}

HMG performed a literature review of previous code compliance studies and their findings in order to better understand the challenges to successful code compliance strategies in California. Following the literature review, HMG then organized and facilitated a roundtable meeting of experts and market actors 
to: 1) pinpoint specific areas within each of the barriers that need to be addressed, 2) identify which market actors should be targeted, and 3) identify what might be the most cost-effective ways to do so. The document also identified high priority codes and standards proposals for development in the next phase of standards enhancements 2009-2011. The report did not include an actual commercial energy code compliance study.

\section{B.2.2 Quantec 2008}

Quantec conducted a code compliance analysis, reviewing a prior NEEA-funded residential study, and using the study's data, generated compliance distributions by state (ID, MT, OR, and WA), housing, type, and component. The report did not include an actual commercial energy code compliance study.

\section{B.2.3 Maine (Maine PUC 2004)}

This study was concerned with the administrative aspects of the evaluation and compliance process and was found to not be of interest for the literature review. Its focus is very broad in the area of energy codes and does not include any specific methodology for compliance evaluation.

Contractor: Public Utilities Commission

Client: Massachusetts Energy Efficiency Program Administrators

Study Date: 2004

Code: ASHRAE 90.1 - 2001

\section{B.2.3.1 Method}

- NA

\section{B.2.3.2 Recommendations}

- Recommends a half-step towards compliance since no commercial code enforcement exists.

- Recommends a hybrid municipal approach to evaluation where local focus on small or common building and private sector inspectors evaluate larger, more complex buildings. This is cost-effective while covering the widest range of buildings. Only Pennsylvania used this model at the time of this study. 



\section{Appendix C}

\section{Comparison of Sample Quality and Compliance Metrics}





\section{Appendix C}

\section{Comparison of Sample Quality and Compliance Metrics}

The tables below compare several of the studies at a glance based on key questions identified to be addressed as part of this literature review. It is quickly apparent based on the items marked in red ("Not Reported," "None," or "No") that several of the key questions were not addressed by the studies. Table C.1 and Table C.2 compare the sample quality questions across the "pilot studies" and "other studies" categories. Sample quality is the metric used to determine if the sample is representative of the population from which it was pulled, if the sample exhibits a similar level of variation as the population from which it was pulled and if the sample is of sufficient size to produce reliable results. Note that the NY and VT studies are grouped with "pilot studies” in Table C.1 and Table C.3 for ease of reporting so all studies can fit in two tables.

Table C.3 and Table C.4 compare the compliance evaluation metric questions. Compliance evaluation metrics deal with how compliance was defined in the study. In the case of the pilot studies, the table is not very informative due to the fact that compliance was defined in the same manner as the BECP methodology. There is a bit more variation across the other studies, and the table provides a snap shot comparison of compliance definitions that were used, however, there were still many cases where compliance was not specifically defined. 

Table C.1. Sample Quality Questions - Pilot Studies

\begin{tabular}{|c|c|c|c|c|c|c|}
\hline & & \multicolumn{5}{|c|}{ Pilot Studies } \\
\hline & & GA & WI & UT & VT & NY \\
\hline & Contractor & $\begin{array}{l}\text { B\&F Technical Code } \\
\text { Services } \\
\end{array}$ & $\begin{array}{l}\text { WI Safety and Buildings } \\
\text { Division }\end{array}$ & Colorado Code Consulting & Navigant & $\begin{array}{l}\text { Vermont Energy } \\
\text { Investment Corp }\end{array}$ \\
\hline \multicolumn{7}{|c|}{ Sample Quality } \\
\hline \multicolumn{7}{|c|}{ This section covers sample quality and the question of representativeness. } \\
\hline & Data/Universe & $\begin{array}{l}\text { Buildings identified via } \\
\text { GA Dept. Comm. Affairs } \\
\text { working group }\end{array}$ & $\begin{array}{c}\text { WI Safety and Bldgs } \\
\text { Division regulated objects } \\
\text { db \& personal contacts }\end{array}$ & Not Reported & $\begin{array}{l}\text { VT Div. of Fire Safety } \\
\text { database; Burlington } \\
\text { Electric customer data }\end{array}$ & Dodge \\
\hline $\begin{array}{l}\text { sample quality } \\
\text { categories }\end{array}$ & Sample description & & $\begin{array}{l}17 \text { bldgs identified by } \\
\text { municipalities, } 27 \\
\text { identifed by state }\end{array}$ & $\begin{array}{c}\text { No evaluation completed; } \\
\text { for educational purposes } \\
\text { only }\end{array}$ & $\begin{array}{c}\text { They basically built a } \\
\text { database from State data }\end{array}$ & $\begin{array}{l}\text { ENERGYSTAR \& LEED } \\
\text { excluded }\end{array}$ \\
\hline 1 & Sampling method & $100 \%$ convenience & $\begin{array}{l}38 \% \text { of sample from } \\
\text { stratified random, } 62 \% \\
\text { convenience }\end{array}$ & Not Reported & Simple random & $\begin{array}{c}\text { Simple random } 1 \text { st round } \\
\text { + not stated } 2 \text { nd round }\end{array}$ \\
\hline \multirow{2}{*}{2} & Size strata & Not Reported & 4 & Not Reported & 7 & 3 \\
\hline & Size strata representativeness measure & Not Reported & Yes & Not Reported & No & No \\
\hline \multirow{2}{*}{3} & State-level Climate Stratification & Not Reported & Not Reported & Not Reported & NA; single zone state & Yes \\
\hline & $\begin{array}{l}\text { Climate strata representativeness measure } \\
\text { reported }\end{array}$ & Not Reported & Not Reported & Not Reported & N/A & No \\
\hline \multirow{2}{*}{4} & State-level Geographic Stratification & Not Reported & Yes & Not Reported & Yes & No \\
\hline & $\begin{array}{l}\text { Geographic strata representativeness measure } \\
\text { reported }\end{array}$ & Not Reported & Yes & Not Reported & No & No \\
\hline \multirow{2}{*}{5} & Number of Building Type Strata & Not Reported & Not Reported & Not Reported & 15 & 10 \\
\hline & $\begin{array}{l}\text { Building type strata representativeness measure } \\
\text { reported }\end{array}$ & Not Reported & Not Reported & Not Reported & None & Not Reported \\
\hline 6 & Building Type Categories Used & Not Reported & Not Reported & Not Reported & Not Reported & Not Reported \\
\hline \multirow{2}{*}{7} & NC or renovation stratification & Not Reported & No & Yes & Yes & Not Reported \\
\hline & $\begin{array}{l}\text { NC or renovation strata representativeness } \\
\text { measure reported }\end{array}$ & Not Reported & No & Not Reported & Not reported & Not Reported \\
\hline \multirow[t]{2}{*}{8} & Attrition/non-response reported & Not Reported & Not Reported & Not Reported & $6 \%$ & Not Reported \\
\hline & Sample size (on-site visits) & $69(44)$ & 44 & 10 & 58 & 26 \\
\hline 9 & Sample size justification & State Sample Generator & State Sample Generator & Not Reported & Statistical & Not Reported \\
\hline 10 & Confidence interval provided? & State Sample Generator & Not Reported & NA & $90 / 10$ & None \\
\hline
\end{tabular}


Table C.2. Sample Quality Questions - Other Studies

\begin{tabular}{|c|c|c|c|c|c|c|c|c|c|}
\hline & & \multicolumn{8}{|c|}{ Other studies } \\
\hline & & WA \& OR 1991 & WA \& OR 1992 & WA 1997 & ID, MT, OR, WA 2008 & CA 2010 & IL 2011 & NE 2014 & MA 2012 \\
\hline & Contractor & Ecotope & Ecotope & Ecotope & Ecotope & KEMA & APEC & Britt Makela & KEMA/Cadmus \\
\hline \multicolumn{10}{|c|}{ Sample Quality } \\
\hline & \multicolumn{9}{|l|}{$\begin{array}{l}\text { This section covers sample quality and the } \\
\text { question of representativeness. }\end{array}$} \\
\hline & Data/Universe & Dodge & Dodge & Dodge & Dodge & Dodge & Dodge & $\begin{array}{l}\text { Aggregated from } \\
\text { jurisdictions directly }\end{array}$ & Dodge \\
\hline $\begin{array}{l}\text { sample quality } \\
\text { categories }\end{array}$ & Sample description & WA and $O R$ & WA and $O R$ & WA & $\mathrm{ID}, \mathrm{MT}, \mathrm{OR}, \mathrm{WA}$ & $\begin{array}{l}1 \text { util territory in } \\
\text { California }\end{array}$ & 35 jurisdictions & $\begin{array}{l}\text { developed list from State } \\
\text { data }\end{array}$ & MA \\
\hline 1 & Sampling method & Simple random sample & Simple random sample & $\begin{array}{c}\text { Stratified random for SM+ } \\
\text { proportional L }\end{array}$ & Stratified random sample & Stratified random sample & $\begin{array}{l}\text { Partial convenience } \\
\text { sample }\end{array}$ & State Sample Generator & Not reported \\
\hline \multirow{2}{*}{2} & Size strata & Not Reported & 2 & 3 & 8 & Not Reported & 3 & Not Reported & 4 \\
\hline & Size strata representativeness measure & Not Reported & Yes & Yes & No & Not Reported & No & Not Reported & No \\
\hline \multirow[b]{2}{*}{3} & State-level Climate Stratification & Not Reported & Not Reported & Not Reported & No & Partial & Not Reported & $\mathrm{NA}$; single zone state & $\mathrm{NA}$; one zone state \\
\hline & $\begin{array}{l}\text { limate strata representativeness measure } \\
\text { reported }\end{array}$ & Not Reported & Not Reported & Not Reported & No & Not Reported & Not Reported & NA & NA \\
\hline \multirow[b]{2}{*}{4} & State-level Geographic Stratification & No & Yes & Yes & Yes & Yes & Partial & Yes & Yes \\
\hline & $\begin{array}{l}\text { Geographic strata representativeness measure } \\
\text { reported }\end{array}$ & No & Yes & Yes & No & Not Reported & Not Reported & Not Reported & Not Reported \\
\hline \multirow{2}{*}{5} & Number of Building Type Strata & 4 & 11 & 11 & 14 & Not Reported & Not Reported & 17 & 9 \\
\hline & $\begin{array}{l}\begin{array}{l}\text { Building type strata representativeness } \\
\text { measure reported }\end{array} \\
\end{array}$ & Not Reported & Yes & Yes & None & Not Reported & Not Reported & Yes, logical & Not Reported \\
\hline 6 & Building Type Categories Used & Not Reported & None & None & Not Reported & Not Reported & Not Reported & Not Reported & Not Reported \\
\hline \multirow[b]{2}{*}{7} & NC or renovation Stratification & Not Reported & Not Reported & No & Yes & Not Reported & Not Reported & None & Not Reported \\
\hline & $\begin{array}{l}\text { NC or renovation strata representativeness } \\
\text { measure reported }\end{array}$ & Not Reported & Not Reported & No & No & Not Reported & Not Reported & None & Not Reported \\
\hline \multirow[t]{2}{*}{8} & Attrition/non-response reported & $86 \%$ & $49 \%$ & $59 \%$ & $38 \%$ & $9 \%$ & Not Reported & Not Reported & $56 \%$ \\
\hline & Sample Size (on-site visits) & 5 & 70 & 88 & 350 & 81 & 10 & 38 & 71 \\
\hline 9 & Sample size justification & Not Reported & Statistical & Statistical & Statistical & Not Reported & State Sample Generator & State Sample Generator & Not Reported \\
\hline 10 & Confidence interval provided? & None & Not Reported & Not Reported & $90 / 10$ & Not Reported & Not Reported & State Sample Generator & Not Reported \\
\hline
\end{tabular}


Table C.3. Compliance Metrics - Pilot Studies

\begin{tabular}{|c|c|c|c|c|c|c|}
\hline & & \multicolumn{5}{|c|}{ Pilot Studies } \\
\hline & & GA & WI & UT & VT & NY \\
\hline & Contractor & $\begin{array}{l}\text { B\&F Technical Code } \\
\text { Services }\end{array}$ & $\begin{array}{l}\text { WI Safety and Buildings } \\
\text { Division }\end{array}$ & Colorado Code Consulting & Navigant & $\begin{array}{l}\text { Vermont Energy } \\
\text { Investment Corp }\end{array}$ \\
\hline \multicolumn{7}{|l|}{ Results } \\
\hline & \multicolumn{6}{|c|}{$\begin{array}{l}\text { This section answers question How the study defined compliance. The traditional definition of compliance } \\
\text { is: average compliance by building pass/fail). This means that the prescriptive requirement must have been } \\
\text { met if a building was to be considered to be compliant. }\end{array}$} \\
\hline \multirow[b]{2}{*}{1} & Percentage of requirements met & $80 \%$ & $95 \%$ & Not Reported & $88 \%$ & NA \\
\hline & Are results weighted? & NA & $\begin{array}{l}\text { Not required for stratified } \\
\text { random; but some of } \\
\text { samble also convenience }\end{array}$ & NA & Yes & NA \\
\hline \multirow{2}{*}{2} & Average compliance by system & NA & NA & Not Reported & NA & NA \\
\hline & Are results weighted? & NA & NA & NA & NA & NA \\
\hline \multirow{2}{*}{3} & Average compliance by building pass/fail & NA & NA & Not Reported & NA & $85 \%$ \\
\hline & Are results weighted? & NA & NA & N/A & NA & square foot \\
\hline \multirow{2}{*}{4} & Average compliance by building with trade offs & NA & NA & Not Reported & NA & $36 \%$ \\
\hline & Are results weighted? & NA & NA & NA & NA & square foot \\
\hline & $\begin{array}{l}\text { Strict assessment of statistically appropriate } \\
\text { results }\end{array}$ & Yes & $\begin{array}{l}\text { Cannot determine due to } \\
\text { lax sample selection }\end{array}$ & No & Yes & Yes \\
\hline
\end{tabular}


Table C.4. Compliance Metrics - Other Studies

\begin{tabular}{|c|c|c|c|c|c|c|c|c|c|}
\hline & & & & & Other & & & & \\
\hline & & WA \& OR 1991 & WA \& OR 1992 & WA 1997 & ID, MT, OR, WA 2008 & CA 2010 & IL 2011 & NE 2014 & MA 2012 \\
\hline & Contractor & Ecotope & Ecotope & Ecotope & Ecotope & KEMA & APEC & Britt Makela & KEMA/Cadmus \\
\hline Results & & & & & & & & & \\
\hline & $\begin{array}{l}\text { This section answers question How the study } \\
\text { compliance by building pass/fail. This means } \\
\text { considered to be compliant. }\end{array}$ & $\begin{array}{l}\text { compliance. The } \\
\text { prescriptive requ }\end{array}$ & $\begin{array}{l}\text { tional definition of comp } \\
\text { ent must have been met }\end{array}$ & $\begin{array}{l}\text { : average } \\
\text { ding was to }\end{array}$ & & & & & \\
\hline & Percentage of requirements met & Not reported & Not reported & N/A & NA & NA & Not reported & NA & NA \\
\hline & Are results weighted? & NA & NA & N/A & NA & NA & NA & NA & NA \\
\hline & Average compliance by system & Not reported & $51 \%$ for WA; $54 \%$ for OR & $47 \%$ & $82 \%$ & $80 \%$ & Not reported & NA & $80 \%$ \\
\hline & Are results weighted? & NA & NA & Yes & No & No & NA & NA & No \\
\hline & Average compliance by building pass/fail & Not reported & Not reported & $60 \%$ & NA & NA & Not reported & $83 \%$ & $83 \%$ \\
\hline & Are results weighted? & NA & NA & No & NA & NA & NA & square foot & square foot \\
\hline & Average compliance by building with trade offs & Not reported & Not reported & NA & NA & NA & Not reported & NA & NA \\
\hline & Are results weighted? & NA & NA & NA & NA & NA & NA & NA & NA \\
\hline & $\begin{array}{l}\text { Strict assessment of statistically appropriate } \\
\text { results }\end{array}$ & No & Yes & Yes & No & No & No & Yes & Yes \\
\hline
\end{tabular}





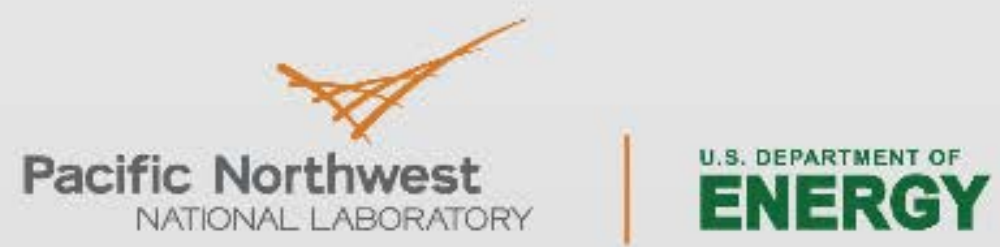

Proudly Operated by Ballelle Since 1965

902 Battele Boulevard

P.O. Box 999

Richland, WA 99352

1-888-375-PNNL (7665)

www.pnnl.gov 